\title{
Local Corruption and Global Capital Flows
}

THE RESEARCH REPORTED in this paper was inspired by a plane ride I took from China to the United States in 1996. Browsing the newspapers and in-flight magazines, I came across one story about the high level of official corruption in China, and another that extolled the extraordinarily large flow of foreign direct investment (FDI) into China that year. ${ }^{1}$ Later in the flight, I struck up a conversation with the passenger sitting next to me, an American business executive who had just visited his joint venture firm in China. I asked him whether the corruption problem in China affected him and his business. He said that it did and went on to explain the myriad problems that his firm had encountered in dealing with corruption and bureaucratic red tape.

During and after that flight, I reflected on whether corruption has generally worked as a beneficial "grease," a minor annoyance, or a major obstacle for international investors. In this paper I address three interrelated issues. First, does corruption reduce inward FDI? Second, is China

This research project is supported in part by a grant from the OECD Development Center. I thank Jeffrey Frankel, David Parsley, Helmut Reisen, Dani Rodrik, and especially Andrei Shleifer and other participants at the Brookings Panel conference for helpful comments, and Rachel Rubinfeld and Yi Wu for superb research and editorial assistance. The views in the paper are my own and may not be those of the Brookings Institution, the OECD Development Center, or any other organization that I am or have been associated with.

1. This was at a time when China was being called "the world's strongest magnet for overseas investment." P. T. Bangsberg, "China Projects Another Record Investment Year, European, Japanese, U.S. Firms Top List," Journal of Commerce, December 27, 1996, p. 3A. I found this quotation some time after the plane ride. 
an exceptional case in which corruption does not do much harm? Third, does corruption distort the composition of capital inflows in a way that might raise the likelihood of a currency crisis?

International direct investment reached $\$ 3.5$ trillion in 1997. A small number of countries in the industrial world account for the bulk-about 68 percent-of this investment. ${ }^{2}$ Yet international direct investment is especially important for developing countries, for which it is not only a source of scarce capital but also an important conduit for the transfer of technological and managerial know-how. ${ }^{3}$

The recent currency crises in East Asia, Russia, and Latin America have highlighted the importance of the composition of capital flows for developing countries. Before I attempt to explain the relationship between corruption and the composition of capital inflows, it is worth noting that there are at least two views on the causes of these crises. One increasingly widespread view is that so-called crony capitalism - the misallocation of financial resources to the friends and relatives of government officials-is partly responsible. However, there is so far virtually no systematic evidence to support or reject this hypothesis. ${ }^{4}$ The other view is that the confidence of international creditors in developing economies is fragile, so that small changes in the outlook can give rise to self-fulfilling expectations of a crisis.

These two explanations are typically presented as rivals, but there may be a link between them. The extent of corruption in a country may affect that country's composition of capital inflows in a way that makes it more vulnerable to shifts in international creditors' expectations. Corruption here refers to the extent to which firms or individuals need to pay bribes to government officials to obtain permits, licenses, loans, or other government services needed to conduct business in a country. ${ }^{5}$

2. United Nations Conference on Trade and Development (1998).

3. Borensztein, De Gregorio, and Lee (1995); Eaton and Tamura (1996).

4. For surveys of the literature on corruption and economic development, see Bardhan (1997), Kaufmann (1997), and Wei (1999). More recent papers on corruption include Wei (2000b) and Bai and Wei (2000). None of the surveys covers any empirical study that links crony capitalism with currency crises.

5. This paper uses the term "crony capitalism" interchangeably with "corruption." Although "crony capitalism" has a more limited meaning, in reality its presence almost always implies widespread corruption, as firms and citizens in such an environment find it necessary to pay bribes to government officials in order to get anything done. 
Several studies have shown that the composition of international capital inflows is correlated with the incidence of currency crises. ${ }^{6}$ They have found that the lower the share of FDI in total capital inflows, or the higher the ratio of short-term debt to reserves, the more likely a currency crisis becomes. One possible reason is that bank lending or other portfolio investment may be driven more by sentiment than direct investment is. Hence a small, unfavorable change in the recipient country's fundamentals may cause a large swing in portfolio capital flows, from massive inflows to massive outflows. This can strain the country's currency or financial system sufficiently to cause or hasten its collapse. ${ }^{7}$ To my knowledge, no studies have examined the connection between corruption (or the intrusiveness of national bureaucracy more generally) and the composition of capital inflows. This paper seeks to fill that void.

A small number of previous papers have looked at the effect of corruption on FDI. Combining corruption with twelve other variables to form a composite indicator, Ashoka Mody and David Wheeler failed to find a significant relation between corruption and foreign investment. ${ }^{8}$ However, this result may have been due to a high noise-to-signal ratio in their composite indicator. Examining U.S. outward investment to individual countries, James Hines found that foreign investment is negatively related to host-country corruption, which he interpreted as evidence of the effect of the U.S. Foreign Corrupt Practices Act. ${ }^{9}$ Using a matrix of bilateral international direct investment from twelve source countries to forty-five host countries, Wei found that FDI flows from the United States were not statistically different from those from other source countries in terms of their degree of aversion to host-country corruption. ${ }^{10}$ More important, corruption had not only a negative and statistically significant coefficient in these analyses, but an economically large effect on inward FDI as well. For example, in a benchmark estimation, an increase in corruption from the level of Singapore to that of Mexico has the same negative effect on inward FDI as raising the marginal corporate tax rate by 50 percentage

6. The first of these was Frankel and Rose (1996), followed by Radelet and Sachs (1998) and Rodrik and Velasco (1999).

7. Radelet and Sachs (1998); Rodrik and Velasco (1999); Reisen (1999).

8. Mody and Wheeler (1992).

9. Hines (1995). The Foreign Corrupt Practices Act of 1977 makes it illegal for U.S.headquartered firms to pay bribes to foreign officials.

10. Wei (2000a). 
points. Using firm-level investment plan data, Beata Smarzynska and Wei found that host-country corruption induces foreign investors to favor joint ventures over wholly owned subsidiaries. ${ }^{11}$

Many host countries have a variety of restrictions on the ability of foreign firms to operate in their territory. For example, foreign investors may be forbidden from entering certain sectors, from exercising full control over their foreign affiliates, or from freely engaging in foreign exchange transactions that allow them to import intermediate inputs or repatriate profits. Of course, many countries also have policies designed specifically to attract foreign investment. These can range from tax concessions and subsidized loans to special incentives for export-related foreign investment. Notably absent from existing studies are empirical measures of either these restrictions or these incentives in the relevant regressions. As far as I know, a cross-country data set on these restrictions and incentives has not existed before now. Yet their omission could be significant. For example, if corruption and restrictions on FDI are positively correlated (that is, if corrupt countries are also more likely to impose restrictions on foreign investment), the findings of previous studies could exaggerate the effect of corruption on inward FDI.

There are reasons to think that corruption and restrictions on FDI might indeed be positively correlated. Andrei Shleifer and Robert Vishny provided a conceptual framework in which bureaucratic interference (such as license requirements) is endogenously determined to extract bribes. ${ }^{12} \mathrm{In}$ such a setting, red tape and bribes could be positively correlated. Using data from firm-level surveys, Daniel Kaufmann and Wei indeed found evidence that firms that pay more bribes also face more, not less, bureaucratic intrusion in equilibrium. ${ }^{13}$ This could come about because both the level of corruption and the level of red tape are endogenously determined in response to characteristics of the sector or the firm in question. On the flip side, if host governments systematically offer incentives to foreign investors in an effort to compensate for corruption problems in their country, previous estimates of the effect of the corruption that do not adequately control for these incentives could be biased downward. Together these considerations suggest that the omission of host governments' policies 
toward FDI could have a profound influence on the estimated effect of corruption on FDI.

As a first contribution to this literature, this paper presents data on a new cross-country measure of restrictions and incentives on inward FDI. Scoring on this measure is based on my reading of detailed descriptions in a series of investment guides for individual countries produced by a worldwide consulting and accounting firm. ${ }^{14}$ The paper then embeds these two new variables in an empirical reexamination of the effect of corruption on foreign investment.

The paper's second contribution is an examination of the effect of corruption on the composition of capital inflows (FDI versus borrowing from foreign banks, in particular). This is done by effectively comparing possibly different effects of corruption on different forms of capital flows. I am not aware of any previous study that has looked at this issue from an empirical standpoint.

It is important to note how "corruption" is interpreted in the paper. Bureaucratic corruption, excessive red tape, corruption in the judicial system, and absence of the rule of law are all different dimensions of poor public governance, but because they tend to be highly correlated, it is difficult to isolate their separate effects. Consequently, "corruption" in the paper should be interpreted more broadly as "poor public governance" rather than as bureaucratic corruption narrowly defined.

\section{Corruption and the Volume of Foreign Direct Investment}

I begin by investigating the effect of bureaucratic corruption on the volume of inward FDI, paying special attention to measuring and controlling for the effect of government policies toward this investment.

\section{Measuring Corruption and Government Restrictions on FDI and Incentives for FDI}

The key variables in the regressions that follow are measures of the volume of bilateral international direct investment, the composition of capital flows, corruption, and governments' policies toward FDI. These

14. The series is the Doing Business and Investing series published by PricewaterhouseCoopers (2000). 
key variables are discussed briefly here and more comprehensively in appendix A.

VOLUME OF INTERNATIONAL DIRECT INVESTMENT. The analysis attempts to explain two aspects of international capital flows. The first is the volume of bilateral direct investment. For this purpose I use end-ofyear stock data for fourteen source countries and fifty-three host countries from table 8 of the International Direct Investment database of the Organization for Economic Cooperation and Development. ${ }^{15}$ To reduce the influence of year-to-year fluctuations, I use the average over 1994-96 as the left-hand-side variable.

COMPOSITION OF CAPITAL FLOWS. To examine the composition of capital inflows, I calculate the ratio of foreign bank borrowing to FDI for each source country-host country pair. Bilateral bank lending data (end-of-year outstanding loans) from thirteen lending countries to eighty-three borrowing countries were obtained from the Bank for International Settlements' Consolidated International Claims of BIS Reporting Banks on Individual Countries. Exclusion of missing observations leaves 793 country pairs. As with bilateral FDI, the data are averaged over 1994-96.

It is preferable to examine the composition of bilateral rather than aggregate capital flows because some of the determinants of these flows are bilateral in nature, such as linguistic and historic ties between the source and the recipient country. Using aggregate data from the balance of payments is likely to introduce more noise. On the other hand, as far as I know, no data on international portfolio flows are available for a matrix of country pairs (with the exception of the United States, for which bilateral outward portfolio investment data are available).

CORRUPTION. Because corruption is illegal and therefore conducted clandestinely, it is inherently difficult to quantify. Three types of measures of corruption are available, all of which are perception-based, subjective indexes. The first type consists of ratings given by in-house experts at international consulting firms. Representative indexes are those of Business International (now part of The Economist's Economic Intelligence Unit) and Political Risk Services Group, which publishes the International Country Risk Guide (and whose ratings are accordingly called ICRG ratings). The second type is based on surveys of business executives or other people in the countries in question. The rating for a country is typically the average of the respondents' ratings. Examples of this include indexes in 
two publications-Global Competitiveness Report (GCR) and World Development Report (WDR) - and an index, first used by Alberto Ades and Rafael Di Tella, derived from interviews with German exporters. All are decribed in more detail below. The third type of corruption measure is based on an average of existing indexes. The best known example is the index produced by Transparency International, a German-based nongovernmental organization devoted to fighting corruption. A drawback of this type of index is that mixing indexes with different country coverage and methodologies can introduce noise into the measure.

In general, corruption ratings based on surveys of firms are preferable to those based on the intuition of in-house experts, for two reasons. First, the executives who respond to surveys like the GCR and WDR surveys presumably have more direct experience with corruption than do the inhouse consultants, each of whom typically has to rate many countries. Second, to the extent that the judgments of individual respondents contain idiosyncratic errors, the averaging process in the GCR and WDR indexes can minimize the influence of such errors. This paper uses the indexes from the GCR and WDR surveys as its basic measure of corruption.

The GCR corruption index is derived from Global Competitiveness Report 1997, produced jointly by the Geneva-based World Economic Forum and the Harvard Institute for International Development. ${ }^{16}$ The GCR survey was conducted in late 1996 on 2,827 firms in fifty-three countries. Question 8.03 of the survey asked respondents to rate, on a scale of one to seven, the level of corruption in the country where they were doing business. The level of corruption was defined as the extent to which respondents observed "irregular, additional payments connected with imports and exports permits, business licenses, exchange controls, tax assessments, police protection or loan applications." The index for a given country was calculated as the average of individual respondents' ratings.

The WDR corruption index is derived from a World Bank survey, conducted in 1996 and early 1997, of 3,685 firms in sixty-nine countries in preparation for its World Development Report $1997 .{ }^{17}$ Question 14 of that survey asked, "Is it common for firms in my line of business to have to pay some irregular, 'additional' payments to get things done?" The respondents were asked to rate the level of corruption, thus defined, on a scale of one to six. The index was then calculated as the country average of the respon-

16. World Economic Forum and Harvard Institute for International Development (1997). 17. World Bank (1997). 
dents' answers. Both the GCR index and the WDR index were originally scaled such that a higher number implies less corruption. To avoid awkwardness in interpretation, they are rescaled in this paper so that a higher number implies more corruption.

The country coverage of the GCR and WDR indexes differs, and each covers only a subset of the countries for which data are available on FDI or other forms of capital flows. This makes it desirable to combine the GCR and WDR indexes into a composite corruption index. Fortunately, the two indexes are derived from surveys with similar methodologies and similar questions - the correlation between the two, for the countries they cover in common, is 0.83 . The composite index is constructed following a simple three-step procedure. First, the GCR index is taken as the benchmark. Next, the ratio of the GCR to the WDR index is computed for all countries that are covered in both surveys. Finally, for those relatively few countries covered by the WDR survey but not by the GCR survey, the WDR rating is converted to the GCR scale using the ratio calculated in the second step.

GOVERNMENT POLICIES TOWARD FDI. This paper's quantification of government policies toward FDI relies on detailed descriptions compiled by PricewaterhouseCoopers (PwC) in its series of country reports, which are written for multinational firms intending to do business in a particular country. The whole series is also available on a single CD-ROM. ${ }^{18}$ Each country report covers a variety of legal and regulatory issues of interest to foreign investors, including restrictions on foreign investment and investors (typically chapter 5), investment incentives (typically chapter 4), and taxation of foreign corporations (typically chapter 16).

For purposes of the present analysis it was necessary to convert the textual information in the $\mathrm{PwC}$ reports into numerical codes. For the measure of restrictions on FDI, a variable was created based on the presence or absence of restrictions in the following four areas:

-controls on foreign exchange transactions (on the grounds that such controls may interfere with foreign firms' ability to import intermediate inputs or repatriate profits);

- exclusion of foreign firms from certain strategic sectors (in particular, national defense and the mass media);

18. PricewaterhouseCoopers (2000). 
- exclusion of foreign firms from other sectors where their presence would be considered harmless in most developed countries; and

-restrictions on the share of foreign ownership (for example, wholly foreign-owned firms may not be allowed, or foreign ownership in a joint venture may not exceed 50 percent).

Each of these four dimensions can be represented by a variable that takes the value of one in the presence of the restriction and zero in its absence. The overall "FDI restrictions" variable is then set equal to the sum of these four variables. Hence the overall variable is zero if there is no restriction in any of the four categories, and four if there are restrictions in each category.

Similarly, an "FDI incentives" index was created using information in the following areas:

- the existence of special incentives for foreigners to invest in certain industries or certain geographic areas;

- tax concessions specific to foreign firms (including tax holidays and tax rebates, but excluding tax concessions specifically designed for export promotion);

- cash grants, subsidized loans, reduced rent for land use, or other nontax concessions, when these are specific to foreign firms; and

-special promotion for exports (including the existence of export processing zones, special economic zones, and the like).

The overall "FDI incentives" variable was created as the sum of these four variables.

Table 1 reports the values of the FDI restrictions and incentives variables by country. Table 2 provides summary statistics on all the key variables and table 3 their pairwise correlations. We define "net incentives" as the difference between the overall incentives variable and the overall restrictions variable. According to this measure, the countries least hospitable to FDI (those for which the value of the net incentives variable is -2 or smaller) are India, the Republic of Korea, Russia, Taiwan, and Ukraine. Those countries that try the most to attract FDI (that is, those whose net incentive ratings are greater than or equal to 2) are Argentina, Israel, the Netherlands, and the United Kingdom.

This coding of the incentives and restrictions measures is still coarse and may not capture the true variations in government policies. Nonetheless, it is important to have a way to control for these government policies in statistical analyses of international capital flows. The contribution 


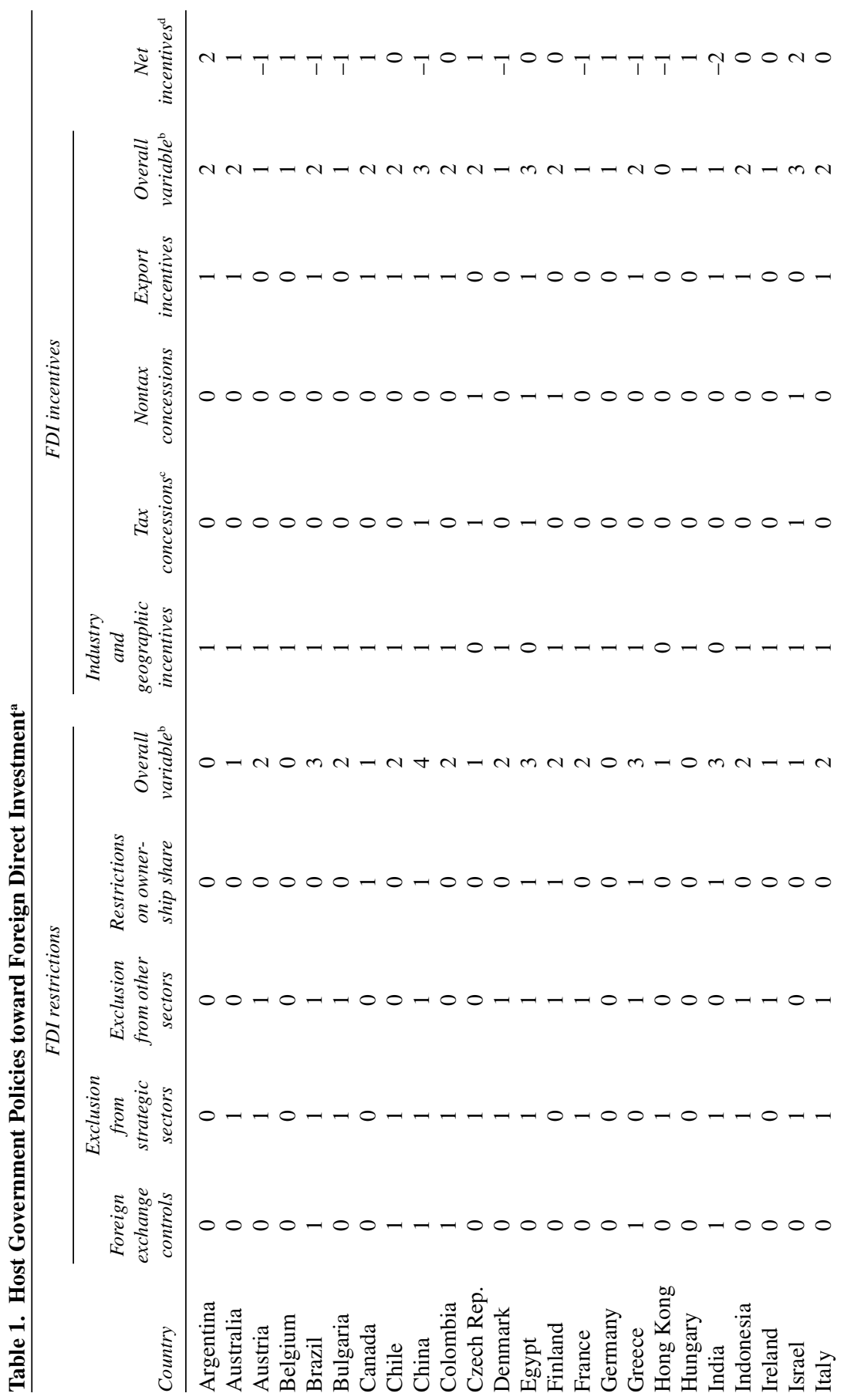




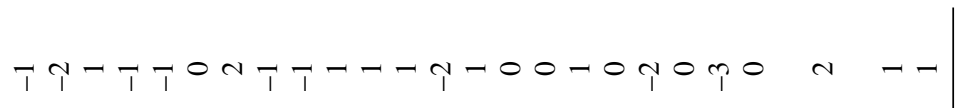

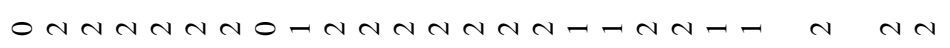

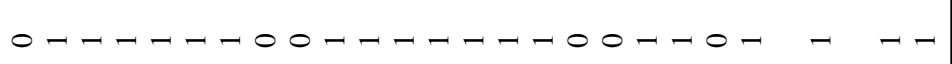

$$
\begin{aligned}
& 0000000000000000000000000 \\
& 00000000000000000000000-0
\end{aligned}
$$

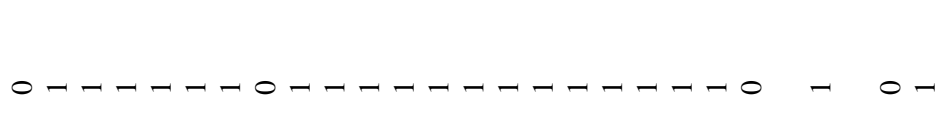

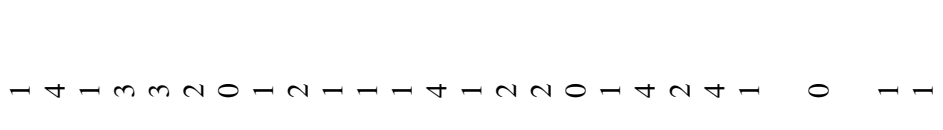

$$
\begin{aligned}
& \text { o-0-10000-00-00-00-0-1000 } \\
& -10-1-00-000-00000-0-0000
\end{aligned}
$$

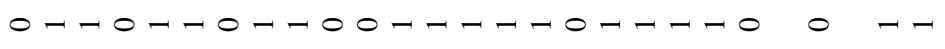

$$
\begin{aligned}
& 0-0-000000-0-0-000-1-0000
\end{aligned}
$$

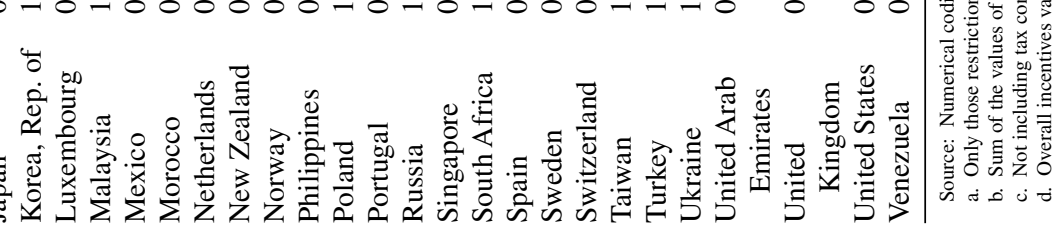


Table 2. Summary Statistics for the Corruption Measures and Other Key Variables

\begin{tabular}{lccccc}
\hline Variable & $\begin{array}{c}\text { No. of } \\
\text { observations }\end{array}$ & Mean & $\begin{array}{c}\text { Standard } \\
\text { deviation }\end{array}$ & Minimum & Maximum \\
\hline $\begin{array}{l}\text { GCR/WDR corruption } \\
\quad \text { index }\end{array}$ & 99 & 3.62 & 1.19 & 1.3 & 5.5 \\
$\begin{array}{l}\text { Transparency International } \\
\quad \text { corruption index }\end{array}$ & 85 & 5.12 & 2.40 & 0 & 8.6 \\
$\begin{array}{l}\text { German exporters } \\
\quad \text { corruption index }\end{array}$ & 103 & 4.58 & 3.11 & 0 & 10 \\
$\begin{array}{l}\text { Corporate tax rate } \\
\quad \text { percent) }\end{array}$ & 56 & 32.39 & 6.86 & 0 & 42 \\
$\begin{array}{l}\text { FDI incentives } \\
\begin{array}{l}\text { FDI restrictions } \\
\text { GDP per capita }\end{array}\end{array}$ & 49 & 1.65 & 0.69 & 0 & 3 \\
\hline
\end{tabular}

Source: Author's calculations.

a. Average over 1994-96 in 1995 dollars.

of this paper is to create the first-of-its-kind index of FDI restrictions and incentives. I will let the empirical results obtained with these data speak to their usefulness.

\section{Baseline Regressions}

We first examine the effect of local corruption on the volume of inward FDI. The specification can be motivated by a simple optimization problem facing a multinational firm. Let $K(j)$ be the stock of investment that the

Table 3. Correlations of the Corruption Measures and Other Key Variables

\begin{tabular}{|c|c|c|c|c|c|c|}
\hline \multirow[b]{2}{*}{ Variable } & \multicolumn{3}{|c|}{ Corruption index } & \multirow[b]{2}{*}{$\begin{array}{l}\text { Corporate } \\
\text { tax rate }\end{array}$} & \multirow[b]{2}{*}{$\begin{array}{c}\text { FDI } \\
\text { incentives }\end{array}$} & \multirow[b]{2}{*}{$\begin{array}{c}F D I \\
\text { restrictions }\end{array}$} \\
\hline & $G C R / W D R$ & $\begin{array}{l}\text { Transparency } \\
\text { International }\end{array}$ & $\begin{array}{c}\text { German } \\
\text { exporters }\end{array}$ & & & \\
\hline $\begin{array}{l}\text { Transparency } \\
\text { International }\end{array}$ & 0.82 & 1.00 & & & & \\
\hline German exporters' & 0.76 & 0.84 & 1.00 & & & \\
\hline Corporate tax rate & 0.08 & 0.16 & -0.07 & 1.00 & & \\
\hline FDI incentives & 0.27 & 0.31 & 0.41 & 0.22 & 1.00 & \\
\hline FDI restrictions & 0.44 & 0.49 & 0.48 & 0.09 & 0.28 & 1.00 \\
\hline GDP per capita ${ }^{a}$ & -0.71 & -0.83 & -0.66 & -0.16 & -0.48 & -0.42 \\
\hline
\end{tabular}

Source: Author's calculations.

a. Average over 1994-96 in 1995 dollars. 
firm will choose to allocate to host country $j$. Let $t(j)$ be the rate of corporate income tax in that country, $b(j)$ be the rate of bribery the firm has to pay per unit of output, and $r$ be the rental rate of capital. Let $f[K(j)]$ be the output of the firm in host country $j$. The firm can invest in any of $N$ possible host countries. It chooses the level of $K(j)$ for $j=1,2, \ldots, N$, in a manner that maximizes its total after-tax and after-bribery profit:

$$
\pi=\sum_{j=1}^{N}\{[1-t(j)-b(j)] f[K(j)]-r K(j)\} .
$$

As a simple way to indicate that taxes and corruption are distortionary, in this equation the factor $[1-t(j)-b(j)]$ premultiplies output rather than profit. The optimal stock of FDI in country $j, K(j)$, would of course be related to both the rate of tax and that of corruption in the host country: $K=$ $K[t(j), b(j)]$, where $\partial K / \partial t<0$ and $\partial K / \partial b<0 .{ }^{19}$

Let $\operatorname{FDI}(k, j)$ be the bilateral stock of foreign direct investment by source country $k$ in host country $j$. The empirical analysis starts with the following baseline specification:

$$
\begin{aligned}
F D I(k, j)= & \sum_{i} \alpha(i) D(i)+\beta_{1} \operatorname{tax}(j)+\beta_{2} \operatorname{corruption}(j) \\
& +\mathbf{X}(j) \delta+\mathbf{Z}(k, j) \gamma+e(k, j),
\end{aligned}
$$

where $D(i)$ is a source-country dummy variable that takes the value of one if the source country is $i$ (that is, if $k=i$ ), and zero otherwise; $\mathbf{X}(j)$ is a vector of characteristics of host country $j$ other than its tax and corruption levels; $\mathbf{Z}(k, j)$ is a vector of characteristics specific to the source country-host country pair; $e(k, j)$ is an independently and identically distributed error that follows a normal distribution; and $\alpha(i), \beta_{1}, \beta_{2}, \boldsymbol{\delta}$, and $\gamma$ are parameters to be estimated.

This is a quasi-fixed-effects regression in that source-country dummies are included. These dummies are meant to capture all characteristics of the source countries, including their size and level of development, that may affect the amount of their outward FDI. In addition, the fixed-effects specification controls for possible differences in the source countries' definition of FDI. This assumes that the FDI values for a particular country pair under these definitions are proportional to each other, except for an addi-

19. A more sophisticated generalization, which is beyond the scope of this paper, would include endogenizing the levels of corruption and of taxation as done by Shleifer and Vishny (1993) or Kaufmann and Wei (1999). 
tive error that is not correlated with the other regressors. The analysis does not impose host-country fixed effects, because doing so would eliminate the possibility of estimating all the interesting parameters, including the effect of corruption.

Table 4 reports a series of regressions using this basic specification and the progressive addition of control variables. In regression equation 4-1, where the corruption and tax variables are included but government policies toward FDI are not, both variables have negative and statistically significant coefficients.

Governments' restrictions on and incentives for foreign investment are added to regression equation 4-2. The incentives and the restrictions have a positive and a negative coefficient, respectively, consistent with intuition. Both are statistically significant. In this regression that controls for government policies toward FDI, the effect of corruption declines a bit yet remains statistically significant. Furthermore, the negative effect of corruption is quantitatively significant as well. A one-standard-deviation increase in the tax rate (by 6.86 percentage points according to table 2) would reduce inward FDI by 19.7 percent. ${ }^{20}$ In contrast, a one-standarddeviation increase in corruption (by 1.19 index points) would reduce inward FDI by 28.3 percent, ${ }^{21}$ a far greater magnitude. To make the point another way, a rise in the host country's corruption from that prevailing in Singapore to that prevailing in Russia (that is, a rise in corruption by $5.3-1.6=3.7$ on the GCR/WDR scale) would reduce FDI by 65 percent. That is equivalent to raising the marginal corporate tax rate by 32 percentage points. ${ }^{22}$

Regression equation 4-3 adds exchange rate volatility and the average government deficit as regressors. A country with a larger government deficit tends to receive less inward FDI. The coefficient on exchange rate volatility is not significant. When these variables are controlled for, the effect of corruption on the volume of FDI remains negative and statistically significant. Exchange rate volatility can be thought of as indicating the stability of a country's monetary policy. As another such measure, the

20. $\operatorname{Exp}(-0.032 \times 6.86)-1=-0.197$.

21. $\operatorname{Exp}(-0.280 \times 1.19)-1=-0.283$.

22. The percentage reduction in FDI associated with the rise in corruption is $\exp (-0.28$ $\times 3.7)-1=-0.645$. The tax equivalent of the rise in corruption is $(-0.28 \times 3.7) /-0.032$ $=32.4$. 
Table 4. Explaining Foreign Direct Investment with Corruption and Other Factors ${ }^{\mathrm{a}}$

\begin{tabular}{|c|c|c|c|c|c|c|}
\hline \multirow{2}{*}{$\begin{array}{l}\text { Independent } \\
\text { variable }\end{array}$} & \multicolumn{6}{|c|}{ Regression equation } \\
\hline & $4-1$ & $4-2$ & $4-3$ & $4-4$ & $4-5$ & $4-6$ \\
\hline Corruption $^{\mathrm{b}}$ & $\begin{array}{l}-0.337 * * \\
(0.068)\end{array}$ & $\begin{array}{l}-0.280 * * \\
(0.070)\end{array}$ & $\begin{array}{l}-0.205^{* *} \\
(0.073)\end{array}$ & $\begin{array}{l}-0.217 * * \\
(0.073)\end{array}$ & $\begin{array}{l}-0.152 * * \\
(0.075)\end{array}$ & $\begin{array}{c}-0.149 * \\
(0.081)\end{array}$ \\
\hline $\begin{array}{l}\text { Corporate tax } \\
\text { rate }\end{array}$ & $\begin{array}{l}-0.028 * * \\
(0.011)\end{array}$ & $\begin{array}{l}-0.032 * * \\
(0.011)\end{array}$ & $\begin{array}{c}-0.003 \\
(0.013)\end{array}$ & $\begin{array}{l}-0.003 \\
(0.013)\end{array}$ & $\begin{array}{c}0.019 \\
(0.017)\end{array}$ & $\begin{array}{c}0.002 \\
(0.012)\end{array}$ \\
\hline FDI incentives & & $\begin{array}{l}0.410 * * \\
(0.093)\end{array}$ & $\begin{array}{l}0.275^{* *} \\
(0.111)\end{array}$ & $\begin{array}{l}0.273^{* *} \\
(0.111)\end{array}$ & $\begin{array}{l}0.410 * * \\
(0.113)\end{array}$ & $\begin{array}{c}0.185^{*} \\
(0.110)\end{array}$ \\
\hline FDI restrictions & & $\begin{array}{l}-0.337 * * \\
(0.058)\end{array}$ & $\begin{array}{l}-0.294 * * \\
(0.060)\end{array}$ & $\begin{array}{l}-0.294 * * \\
(0.060)\end{array}$ & $\begin{array}{l}-0.314 * * \\
(0.064)\end{array}$ & $\begin{array}{l}-0.304 * * \\
(0.058)\end{array}$ \\
\hline $\log \mathrm{GDP}^{\mathrm{c}}$ & $\begin{array}{l}0.864 * * \\
(0.049)\end{array}$ & $\begin{array}{l}0.862 * * \\
(0.053)\end{array}$ & $\begin{array}{l}1.040 * * \\
(0.057)\end{array}$ & $\begin{array}{l}1.039 * * \\
(0.057)\end{array}$ & $\begin{array}{l}0.976^{* *} \\
(0.064)\end{array}$ & $\begin{array}{l}0.998 * * \\
(0.057)\end{array}$ \\
\hline $\begin{array}{l}\text { Log GDP per } \\
\text { capita }^{\text {c }}\end{array}$ & $\begin{array}{l}-0.038 \\
(0.078)\end{array}$ & $\begin{array}{l}-0.019 \\
(0.085)\end{array}$ & $\begin{array}{c}0.026 \\
(0.085)\end{array}$ & $\begin{array}{c}0.005 \\
(0.085)\end{array}$ & $\begin{array}{l}-0.071 \\
(0.095)\end{array}$ & $\begin{array}{l}-0.005 \\
(0.083)\end{array}$ \\
\hline $\log _{\text {distance }}{ }^{\mathrm{d}}$ & $\begin{array}{l}-0.577 * * \\
(0.062)\end{array}$ & $\begin{array}{l}-0.553 * * \\
(0.061)\end{array}$ & $\begin{array}{l}-0.656^{* *} \\
(0.067)\end{array}$ & $\begin{array}{l}-0.660^{* *} \\
(0.066)\end{array}$ & $\begin{array}{l}-0.741^{* *} \\
(0.073)\end{array}$ & $\begin{array}{l}-0.685 * * \\
(0.066)\end{array}$ \\
\hline $\begin{array}{l}\text { Presence of } \\
\quad \text { linguistic tie }\end{array}$ & $\begin{array}{l}1.516^{* *} \\
(0.216)\end{array}$ & $\begin{array}{l}1.437 * * \\
(0.210)\end{array}$ & $\begin{array}{l}1.232 * * \\
(0.214)\end{array}$ & $\begin{array}{l}1.216^{* *} \\
(0.214)\end{array}$ & $\begin{array}{l}0.956^{* *} \\
(0.221)\end{array}$ & $\begin{array}{l}1.189 * * \\
(0.211)\end{array}$ \\
\hline $\begin{array}{l}\text { Exchange } \\
\text { rate volatility }\end{array}$ & & & $\begin{array}{c}2.388 \\
(2.110)\end{array}$ & $\begin{array}{c}2.736 \\
(2.118)\end{array}$ & $\begin{array}{l}7.036^{* *} \\
(2.214)\end{array}$ & $\begin{array}{l}6.654 * * \\
(2.253)\end{array}$ \\
\hline $\begin{array}{l}\text { Government } \\
\text { deficit }^{\mathrm{c}, \mathrm{g}}\end{array}$ & & & $\begin{array}{l}-0.096^{* *} \\
(0.016)\end{array}$ & $\begin{array}{l}-0.096^{* *} \\
(0.016)\end{array}$ & $\begin{array}{l}-0.110^{* *} \\
(0.016)\end{array}$ & $\begin{array}{l}-0.107 * * \\
(0.016)\end{array}$ \\
\hline $\begin{array}{l}\text { U.S. source } \\
\text { effect }^{\mathrm{h}}\end{array}$ & & & & $\begin{array}{l}-0.120 \\
(0.153)\end{array}$ & & \\
\hline $\begin{array}{l}\text { Accounting } \\
\text { standards }^{i}\end{array}$ & & & & & $\begin{array}{l}0.016^{* * *} \\
(0.007)\end{array}$ & \\
\hline Arbitrariness $^{j}$ & & & & & & $\begin{array}{c}-0.270 \\
(0.267)\end{array}$ \\
\hline \multicolumn{7}{|l|}{ Summary statistics } \\
\hline Adjusted $R^{2}$ & 0.72 & 0.73 & 0.76 & 0.76 & 0.79 & 0.76 \\
\hline No. observations & 658 & 628 & 580 & 580 & 467 & 565 \\
\hline
\end{tabular}

a. The equations are fixed-effects regressions in which the dependent variable is the logarithm of annual bilateral flows of FDI between source and host countries (averaged over 1994-96). All regressions include source-country dummy variables whose coefficients are not reported. See appendix A for a full description of the other variables. Standard errors are in parentheses. $* *$ denotes significance at the 5 percent level, and * at the 10 percent level.

b. As measured by the GCR/WDR index.

c. Average over 1994-96.

d. Distance in kilometers between designated economic centers in the two countries.

e. Between source and host country.

f. Standard deviation of the monthly-average exchange rate, in logarithms, from 1994 through 1996.

g. As a percentage of GDP.

h. Product of corruption and a dummy variable that equals one when the United States is the source country.

i. Index taken from La Porta and others (1998).

j. Index taken from Wei (1997). 
average inflation rate was included in other regressions (not reported) but was not significant by itself.

Until recently, the United States was the only major FDI source country in the world that made it a crime for its multinational companies to pay bribes to foreign government officials. ${ }^{23}$ Offending firms face monetary fines, and corporate officers may face jail terms in addition. This suggests the possibility that American firms have been systematically more averse to investing in corrupt countries than firms from other countries. On the other hand, there are also reasons to think that U.S. investors may not be that different. First, American firms may have used their entrepreneurial skills to find covert substitutes for outright cash bribery, for example by sponsoring all-expense-paid travel for foreign government officials. Second, corruption and other dimensions of poor public governance tend to be correlated. Multinational firms from other source countries may be just as averse as U.S. firms to investing in poorly governed countries, which are also likely to be highly corrupt. To sum up, whether U.S. firms are systematically more averse to host-country corruption than other investors is theoretically ambiguous.

To investigate this effect empirically, a term interacting the U.S. sourcecountry dummy and the level of host-country corruption was included as an additional regressor in regression equation 4-4 (the U.S. source dummy by itself has already been included). If American investors are more averse to corruption, the coefficient on the interactive term will be negative. In fact, the point estimate on the new interactive term is -0.12 . However, the relatively large standard error on the coefficient implies that the null hypothesis of a zero coefficient cannot be rejected.

Regression equation 4-5 reports results from adding as another regressor a measure of the quality of a country's accounting standards. This was done to examine the possibility that poor accounting standards in a host country may deter FDI. Good accounting standards are indeed associated with more inward FDI. The estimated effect of corruption on FDI becomes smaller but remains negative and statistically significant.

23. Under the Foreign Corrupt Practices Act of 1977 (see above). Bribery of foreign officials was not a crime for firms from other major source countries until the OECD Convention on Combating Bribery of Foreign Officials in International Business Transactions took effect on February 15, 1999. 
Finally, Shleifer and Vishny have argued that the "industrial organization" of the corruption market matters: is corruption centrally organized and predictable, or is it disorganized and unpredictable? ${ }^{24}$ From individual responses to survey questions on corruption, I previously developed an index of corruption-related arbitrariness. ${ }^{25} \mathrm{It}$ is a three-step process. First, all individual corruption responses are regressed on a set of industry dummies and dummies for firm size, to remove the influence of industrial and firm characteristics on the corruption experience of the respondents. Second, for each country, extreme values (roughly 5 percent of all responses for a given country) are removed in a manner analogous to the scoring in Olympics gymnastics competition. Finally, the standard deviation of the remaining answers for a given country is taken as a measure of that country's corruption-related arbitrariness. This measure is then used as an additional regressor. The idea is that the more arbitrary corruption is, the greater the dispersion in individual firms' experience with corrupt officials should be. This arbitrariness index has a negative and statistically significant effect on inward FDI in regressions that omit the government deficit variable (not reported), but it loses statistical significance once the government deficit is controlled for (regression equation 4-6).

\section{Robustness Checks}

Several robustness checks were performed employing different specifications, a different way of coding the corruption measure, alternative measures of corruption from different sources, and more control variables. Table $\mathrm{C} 1$ in appendix $\mathrm{C}$ reports a series of regressions in which hostcountry random effects were added to the equation (while still maintaining source-country fixed effects). This was done to control for the possibility that FDI from different source countries to a common host country may be correlated because of a common missing variable. The results are broadly consistent with those in the previous tables. In particular, FDI incentives always have a positive effect on FDI, and both corruption and FDI restrictions are negatively associated with inward FDI. Most important for this paper, the coefficient on corruption is negative and statistically significant in all cases.

24. Shleifer and Vishny (1993).

25. Wei (1997). 
These regressions, which treat the corruption indicator as a cardinal index ranging from zero to six, may impose too much linearity in the effect of corruption on FDI. To see whether the result is sensitive to this fine gradation, I also experimented with a coarse partition of the host countries into high-corruption and low-corruption countries, according to whether their corruption index is above or below the median. The results, reported in regression equations $\mathrm{C} 2-1$ and $\mathrm{C} 2-2$ of appendix table $\mathrm{C} 2$, are qualitatively similar to those reported above. The coefficient for the corruption variable is negative and statistically significant.

Since the GCR/WDR measure of corruption is a subjective index, it may be useful to see whether the results continue to hold if one employs alternative measures of corruption from different sources. For this purpose I use the corruption index produced by Transparency International and that derived from interviews with German exporters and used by Ades and Di Tella. ${ }^{26}$ The results, reported in regression equations C2-3 through C2-6 of appendix table $\mathrm{C} 2$, again are qualitatively similar to those presented above: corruption in a host country substantially reduces the volume of inward FDI. Since the original GCR and WDR surveys covered different sets of countries, and potentially different sets of firms even in the countries that appear in both surveys, I also performed regressions with each of these two corruption measures alone. The results (not reported) are essentially the same as when the two corruption ratings are merged.

In all of the previous regressions, the left-hand-side variable is the logarithm of bilateral FDI. Since the logarithm of zero is not defined, all country pairs that have zero FDI were dropped from the regressions. Doing so may, however, bias the estimates. To see whether this data censorship is driving the results, I experimented with a version of the tobit regression in which the left-hand-side variable is defined as $\ln (\mathrm{FDI}+0.1)$. Regression equation $\mathrm{C} 2-7$ in appendix table $\mathrm{C} 2$ reports the results. This adjustment in the specification allows a modest increase in the number of observations (from 580 in equation 4-3 in table 4 to 621 in equation C2-7). Although the magnitude of the point estimates changes a bit, the qualitative inference remains the same. 


\section{Is China Different?}

China is an apparent puzzle. In the 1990s China was often the single largest developing-country host of FDI, according to official balance of payments data reported by China. When one regresses the logarithm of FDI on GDP, GDP per capita, and a dummy for China as a host country, the coefficient on the China dummy is found (in results not reported here) to be positive and significant. In other words, China appears to attract significantly more FDI than its size or level of development suggest that it should. It is these impressive amounts of inward FDI that have led some observers to call China "the world's strongest magnet for overseas investment" or to call the inflows a case of "China fever." ${ }^{27}$ Yet China is also reported to be very corrupt. Does corruption in China reduce inward FDI or not?

This appears to contradict the central message of the previous section. Taking this puzzle head on, I will argue that the correct way to ascertain whether China hosts an unusually large amount of FDI is to first establish a benchmark model that can estimate how much FDI China should have received given its economic characteristics, policies, and other factors. The empirical model in the previous section provides just such a benchmark. Then one can compare what China actually has received with what the model says it should have received.

To begin with the bottom line, the empirical results indicate that, as far as FDI from the world's major source countries is concerned, there is nothing to support the notion that China is a supermagnet for inward FDI. ${ }^{28}$ Thus, corruption is just as damaging to FDI into China as it is elsewhere. Indeed, some weak evidence suggests that China may even be an underachiever as a host of FDI.

27. P. T. Bangsberg, Journal of Commerce, December 27, 1996, p. 3A; The Economist (U.S. edition), March 1, 1997 p. 38.

28. Using FDI data for 1993, Wei (2000c) found that China was actually a substantial underachiever as a host of FDI. But it was only later that labels like "China fever" and "the world's strongest magnet" emerged, making a reexamination necessary. In addition, this paper now provides a comprehensive index on government policies toward FDI, which was not available before. 


\section{Source-Country Composition of Chinese Inward FDI}

The source composition of Chinese FDI is quite unusual. According to the OECD, the five most important source countries in terms of worldwide FDI outflow during 1990-95 were (in order of importance) the United States, Japan, the United Kingdom, France, and Germany. ${ }^{29}$ Collectively, these five countries accounted for over 70 percent of direct investment worldwide. The dominant source of FDI into China, however, is Hong Kong (table 5). Annual FDI inflows from Hong Kong accounted for half or more of all FDI into China in almost every single year during 1992-97, and this dominance tends to be even greater in the earlier years of the period. Similarly, Hong Kong's share of the stock of Chinese FDI is close to 60 percent. Taiwan, Japan, and the United States are the second-, third-, and fourth-largest investors in China (their relative ranking varies from year to year). However, each typically brings in less than a quarter of what Hong Kong invests. The United Kingdom, France, and Germany are also important source countries, but their investments not only lag far behind that of Hong Kong but sometimes are less than those of Singapore and Macao.

Part of the reported FDI from Hong Kong is in fact capital that originated in mainland China and is returning to the mainland disguised as Hong Kong investment. This "round-tripping" is done to take advantage of tax, tariff, and other benefits accorded to foreign investment in China. One estimate puts such "false-foreign" capital at 15 percent of all of Hong Kong's direct investment in China. ${ }^{30}$ That would imply that such investment was on the order of $\$ 3$ billion in 1997, or over 6 percent of the total FDI flow into China that year, according to official statistics.

\section{China as a Host of Direct Investment from the}

\section{Major Source Countries}

The first four columns in table 6 report a series of regressions that add a dummy for China as a host country. If China has truly attracted more FDI than expected for a country with its characteristics, the coefficient on this dummy should be positive and statistically significant. In fact, however,

29. OECD (2000).

30. Huang (1998). 


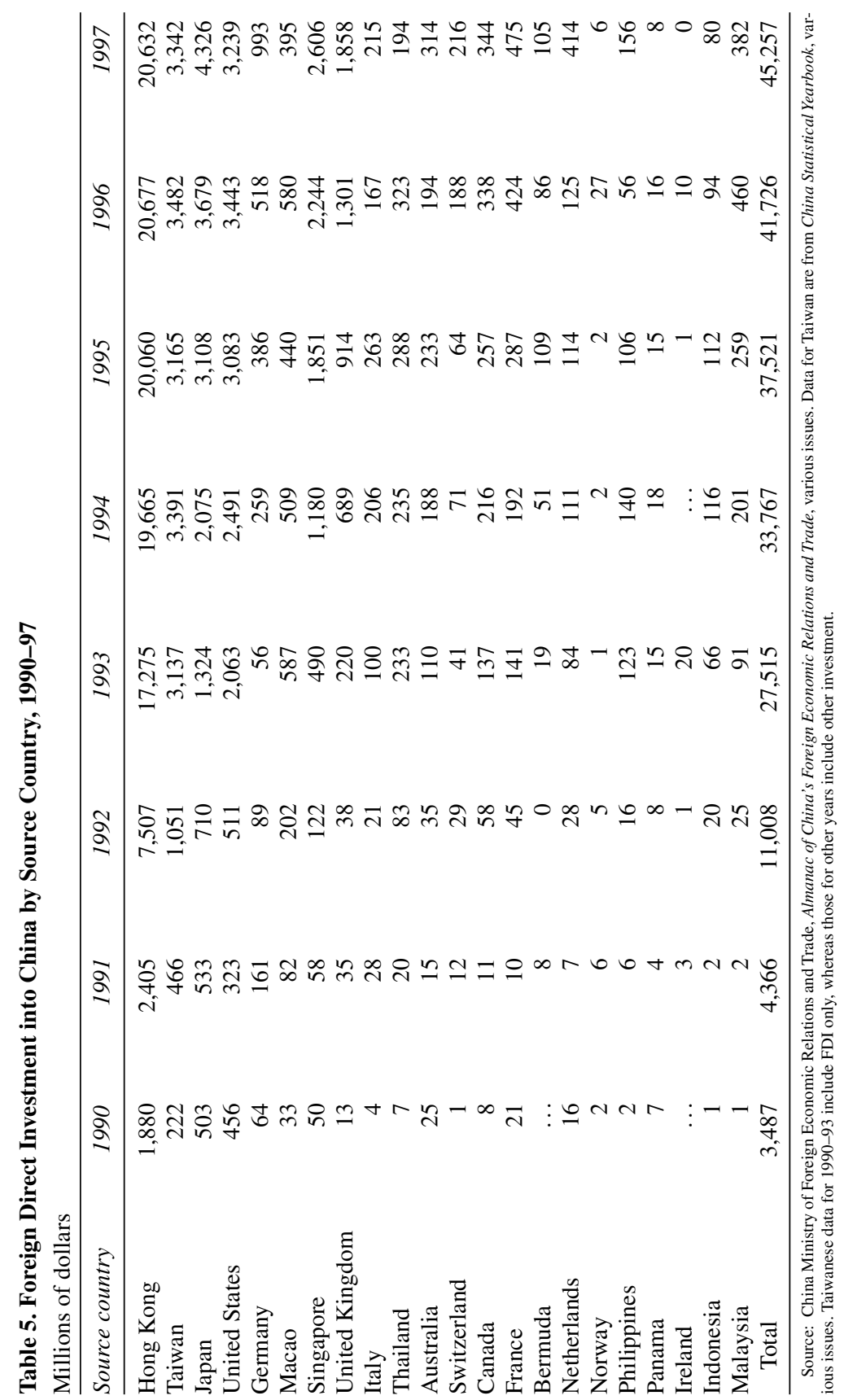




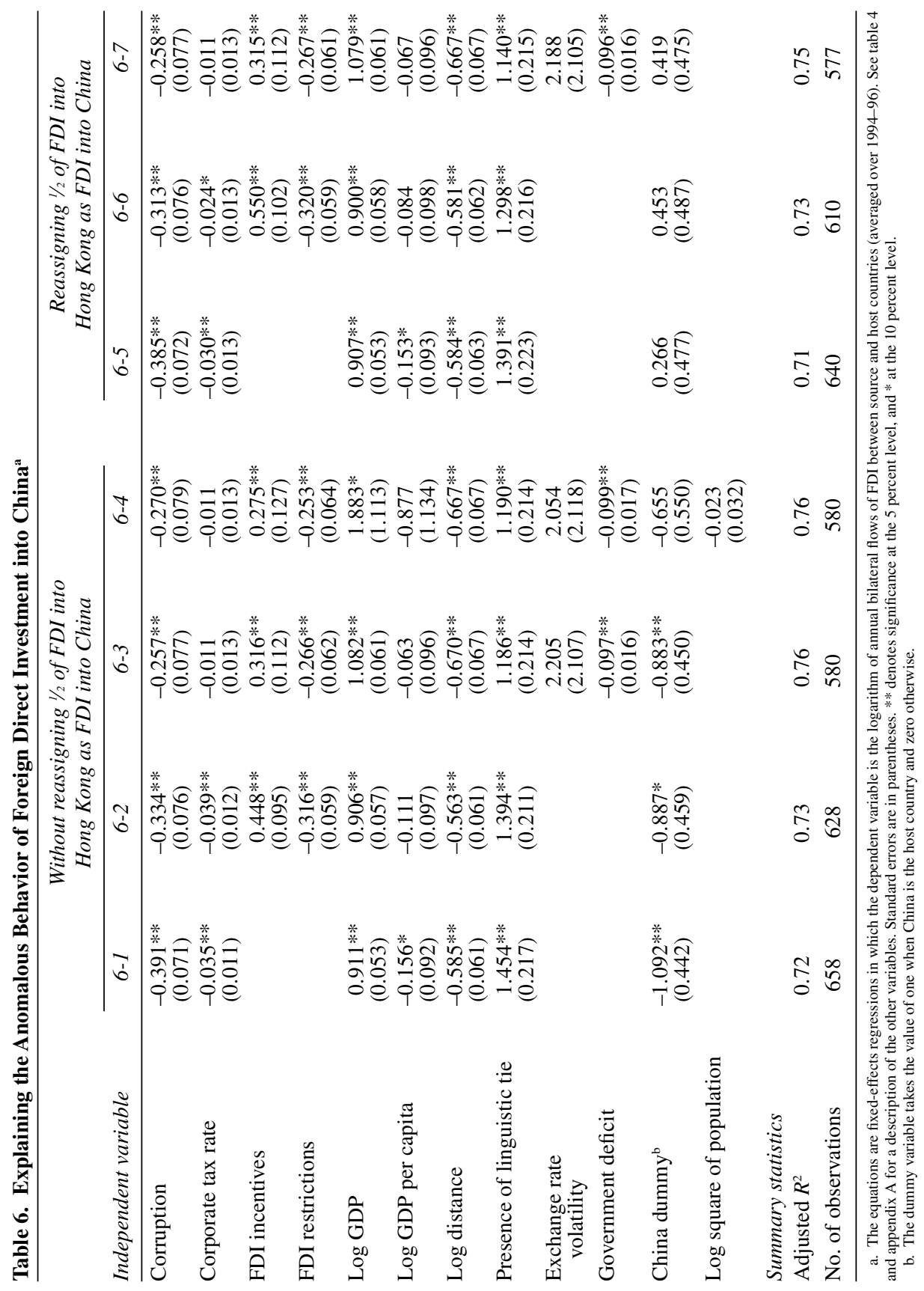


the coefficient on the China dummy is invariably negative and usually statistically significant. In other words, relative to the empirical benchmark, China is an underachiever as a host of FDI, not a superstar.

A possible concern is that the empirical model may penalize more populous countries like China. Therefore regression equation 6-4 reports a regression in which the square of the logarithm of population is included as a regressor. The previous regressions implicitly controlled for the logarithm of population, because $\ln$ (population) is the difference between $\ln$ (GDP) and $\ln$ (GDP per capita). The coefficient on this new regressor turns out not to be different statistically from zero. In any case, the coefficient on the China dummy remains negative.

To conclude, there is absolutely no support for the hypothesis that China is a superachiever as a host of FDI from the world's major source countries. To the contrary, to the extent there is a puzzle about FDI into China, it is why China appears to be an underachiever in this regard.

\section{The Hong Kong Connection}

It is often remarked that Hong Kong is a mecca for FDI. It seems possible that, in part because investors from other source countries loathe the corruption and red tape they encounter on the mainland, they invest heavily in Hong Kong as a stepping-stone to or substitute for investing in mainland China. Indeed, some of Hong Kong's observed investment in China may have been made on behalf of investors from the major source countries.

To see whether the Hong Kong connection helps solve the puzzle of China's underachievement, half of the observed FDI into Hong Kong from the major source countries was reclassified as additional FDI into China from the same source countries. ${ }^{31}$ This is likely an overadjustment, since a substantial part of FDI into Hong Kong is truly destined for Hong Kong. Nonetheless, it is interesting to see whether such a draconian adjustment could turn the China dummy from a significant negative to zero.

The results, reported in the last three equations in table 6 , show that this is indeed the case. This experiment has a high degree of arbitrariness, however. It only serves to demonstrate that the gap between actual FDI into

31. Because data on FDI from Hong Kong to countries other than China are unavailable, FDI from Hong Kong are not part of the data in the regressions. 
China and the potential amount as defined by these regressions is enormous. China may be a uniquely lucky host country (compared with, say, India or Russia) in that Hong Kong may have helped it attract FDI from the major source countries that it would not have received otherwise.

\section{Corruption and the Composition of Capital Inflows}

The composition of capital inflows has important implications: for example, it may affect the likelihood that a country will suffer a currency crisis. To motivate the analysis of capital flow composition that follows, I begin by looking at differences in the volatility of various types of capital flow. I compute the standard deviations of three types of inflow-portfolio capital, bank borrowing, and FDI, all measured as percentages of recipient-country GDP — during 1980-96 for every member country of the International Monetary Fund for which data on all three variables are available. Table 7 shows that, for the subset of OECD countries (twenty countries that were OECD members as of 1980), the volatility of the FDI-to-GDP ratio is substantially smaller than that of the other two ratios. For the nonOECD countries as a group, the FDI-to-GDP ratio is also much less volatile than the loans-to-GDP ratio, but more volatile than the portfolio flow-to-GDP ratio. The table also reports the volatility of the three ratios for a number of individual countries that have featured prominently in the recent currency crises. For each country, the loans-to-GDP ratio is at least twice and as much as fifteen times as volatile as the FDI-to-GDP ratio; the portfolio capital-to-GDP ratio is likewise more volatile than the FDIto-GDP ratio. When the sample period is extended to include 1997 and 1998, the differences in volatility are even more pronounced (results not reported). Therefore the data are consistent with the hypothesis that FDI is less sentiment-driven and hence more stable as a source of foreign capital.

This section studies the connection between the degree of corruption in capital-receiving countries and the composition of capital flows into these countries. In particular, I focus on the size of bilateral direct investment versus that of bilateral bank lending from thirteen developed countries to thirty developing and transition economies. (Except for that originating from the United States, it was not possible to obtain data on nonbank portfolio investment on a bilateral basis.) 
Table 7. Standard Deviations of Ratios of FDI, Bank Lending, and Portfolio Flows to GDP, 1980-96

\begin{tabular}{lccc}
\hline Item & $\begin{array}{c}\text { FDI-GDP } \\
\text { ratio }\end{array}$ & $\begin{array}{c}\text { Bank lending- } \\
\text { GDP ratio }\end{array}$ & $\begin{array}{c}\text { Portfolio flows- } \\
\text { GDP ratio }\end{array}$ \\
\hline OECD (20 countries) & & & \\
Mean & 0.007 & 0.021 & 0.020 \\
Median & 0.006 & 0.017 & 0.019 \\
Non-OECD (73 countries) & & & \\
Mean & 0.022 & 0.044 & 0.011 \\
Median & 0.010 & 0.035 & 0.004 \\
Whole sample (93 countries) & & & \\
Mean & 0.019 & 0.039 & 0.013 \\
Median & 0.009 & 0.033 & 0.009 \\
Selected countries & & & \\
Indonesia & 0.007 & 0.017 & 0.009 \\
Korea, Rep. of & 0.002 & 0.037 & 0.014 \\
Malaysia & 0.023 & 0.034 & 0.023 \\
Mexico & 0.007 & 0.033 & 0.026 \\
Philippines & 0.009 & 0.026 & 0.017 \\
Thailand & 0.007 & 0.028 & 0.012 \\
\hline \multicolumn{2}{l}{ (9) } & &
\end{tabular}

Source: Author's calculations based on data from International Monetary Fund, Balance of Payments Statistics, various issues, and the World Bank's Global Development Finance and World Development Indicators databases.

a. The sample includes those countries for which data for all three variables are available in at least eight years from 1980 to 1996.

Corruption is bad for both international direct investors and international creditors. Corrupt borrowing countries are more likely to default on bank loans and to nationalize (or otherwise diminish the value of) the assets of foreign direct investors. When this happens, there is a limit to how much international arbitration or court proceedings can help to recover the assets, because there is a limit to how much collateral the foreign creditors or direct investors can seize as compensation.

One may argue that domestic investors have an informational advantage over international investors: the former are more likely to have detailed firsthand experience of local markets and business practices. Among international investors, direct investors may have an informational advantage over portfolio investors (and, presumably, over banks engaged in international lending). International direct investors can, for example, obtain information about the local market by stationing managers from headquarters in the host country. These cross-border informational asymme- 
tries may lead to a bias in favor of international direct investment. Indeed, this is the logic underlying one recent theory of the "pecking order of international capital flows." ${ }^{32}$ Corruption, however, could temper this effect. The need for international investors to pay bribes and deal with official extortion tends to increase with the frequency and the extent of their interactions with local bureaucrats. Given that international direct investors are more likely to have repeated interactions with local officials (for permits, taxes, health inspections, and so forth) than international banks or portfolio investors, one would expect local corruption to be more detrimental to FDI than to other forms of capital flows. Along the same line, direct investment involves greater sunk costs than do bank loans or portfolio investment. Once an investment is made, corrupt local officials, knowing that the investment cannot easily be liquidated, may threaten to raise obstacles to that investment's success unless they are paid a bribe. Hence, direct investors would find themselves in a weaker bargaining position than international banks or portfolio investors. This ex post disadvantage of FDI would tend to make international direct investors more cautious ex ante in a corrupt host country than international portfolio investors. $^{33}$

There is a second reason why local corruption might deter international direct investment more than it does international bank credit or portfolio investment. Under the current international financial architecture, international creditors are more likely than international direct investors to be bailed out in time of crisis. For example, during the 1994-95 tequila crisis and the more recent Asian currency crises, the International Monetary Fund, the World Bank, and the Group of Seven countries mobilized a large amount of funds for the affected countries, to prevent or minimize potentially massive defaults on bank loans. An international bailout of bank loans in the event of a severe crisis has by now been embedded firmly in market expectations. (In addition, many developing-country governments implicitly or explicitly guarantee loans to the country's private

32. Razin, Sadka, and Yuen (1998).

33. Tornell (1990) presented a model in which a combination of sunk cost in real investment and uncertainty leads to underinvestment in real projects even when the inflow of financial capital is abundant. 
sector. $)^{34}$ There have been no comparable examples of international assistance packages for the recovery of nationalized or extorted assets of foreign direct investors, except for an insignificant amount of insurance, which is often expensive to acquire. This difference makes banks more willing than direct investors to do business with corrupt countries, further distorting the composition of capital flows.

Both reasons suggest that corruption may affect the composition of capital inflows in a way that makes the host country more likely to experience a currency crisis. Of course, the composition of capital flows affects economic development in ways that go beyond its effect on the propensity for a currency crisis. Indeed, many would argue that attracting FDI, as opposed to international bank loans or portfolio investment, is a more useful way to transfer technology and managerial know-how.

To take some concrete examples, table 8 shows the total amounts of inward FDI, foreign bank loans, and portfolio capital inflows, as well as the ratios of the last two to FDI, for four countries: Singapore, New Zealand, Argentina, and Thailand. Singapore and New Zealand both have relatively low corruption and relatively low ratios of loans to FDI and portfolio investment to FDI. In contrast, Argentina and Thailand have relatively high corruption and relatively high ratios of loans to FDI and of portfolio capital to FDI. These examples are consistent with the notion that local corruption is correlated with the pattern of capital inflows. Of course, these four countries are just examples. Two questions need to be addressed more formally. First, can the association between corruption and the composition of capital flows be generalized beyond these four countries? Second, once we control for a number of other characteristics that affect the composition of capital inflows, is the positive association between corruption and the ratio of loans to FDI still in evidence?

\section{A Minimalist Model}

In the discussion of the empirical analyses below, I will link the ratio of bank borrowing to inward FDI with corruption. Here a simple two-

34. McKinnon and Pill $(1996,1999)$ argue that such government guarantees generate moral hazard, which in turn leads developing countries to overborrow in international credit markets. 
Table 8. Corruption and the Composition of Capital Flows in Selected Countries

\begin{tabular}{lcccc}
\hline Item & Singapore & New Zealand & Argentina & Thailand \\
\hline Corruption $^{\mathrm{a}}$ & 1.6 & 1.8 & 4.5 & 5.5 \\
$\begin{array}{l}\text { Capital flows } \\
\quad \text { millions of dollars) }\end{array}$ & & & & \\
Bank lending & 3,250 & 284 & 4,840 & 777 \\
Portfolio flows & 677 & 193 & 8,380 & 237 \\
FDI & 7,380 & 263 & 4,730 & 134 \\
Ratios to FDI & & & & \\
Bank lending & 0.44 & 0.11 & 1.02 & 5.79 \\
Portfolio flows & 0.09 & 0.07 & 1.77 & 1.76 \\
\hline
\end{tabular}

Source: Author's calculations based on data in International Monetary Fund, Balance of Payments Statistics, various issues. a. As measured by the GCR index.

b. Averages over 1994-96.

period model is used to demonstrate how this specification may be justified. For simplicity, let us assume that there are two types of international capital flows: direct investment and bank credit. Let us suppose that the government in capital-importing country $k$ maximizes the following twoperiod objective function:

$$
U[G(k, 1)]+\delta U[G(k, 2)],
$$

where $G(k, 1)$ and $G(k, 2)$ are government expenditures in country $k$ in the first and second periods, respectively, and $\delta$ is the subjective discount factor. For simplicity, we assume that tax revenues in the two periods, $T(k, 1)$ and $T(k, 2)$, are given exogenously. Let $B(k)$ and $D(k)$ be first-period borrowing by country $k$ from international banks and first-period direct investment in country $k$, respectively. To abstract from unnecessary complications, I assume that bank credit and FDI are merely two forms of additional funding sources. No production is explicitly modeled. In this case the gap between first-period expenditure and tax revenue has to be met by an inflow of international capital:

$$
G(k, 1)=T(k, 1)+B(k)+D(k) .
$$

In the second period, the international credit has to be repaid, and international direct investors are assumed to recoup both the investment and the gross profit on that investment:

$$
G(k, 2)=T(k, 2)-R[B(k)] B(k)-R[D(k)] D(k),
$$


where $R[B(k)]$ and $R[D(k)]$ are the gross returns that international creditors and international direct investors demand from country $k$. Suppose $R^{*}$ is the gross return on a risk-free bond. Then, assume that

$$
R[B(k)]=R^{*}+\theta B(k)
$$

and

$$
R[D(k)]=R^{*}+\theta D(k)+\rho(k) D(k) .
$$

Both $\theta$ and $\rho(k)$ are positive parameters. $\rho(k)$ should be thought of as proportional to country $k$ 's perceived level of corruption. The positive value for $\theta$ reflects the assumption that the warranted return on either bank credit or direct investment increases with the size of the capital inflow. $\rho(k)$ appears in the return on direct investment but not in the return on bank credit, because corruption represents a greater risk to direct investment than to bank loans. This is so both because bank lending enjoys better protection than direct investment under the current international financial system and because direct investment involves greater sunk costs and is more vulnerable to ex post expropriation by corrupt government officials.

Two points are worth noting. First, the model assumes that it is the government that obtains and later repays bank credit. In reality, of course, both the private and the public sector can borrow from the international credit market. Many researchers have observed, however, that the distinction between private and public borrowing in international markets is blurred, because private borrowing often carries an implicit, and sometimes explicit, guarantee from the borrower's government. Second, although direct investment is supposed to be for the long term, investors will eventually want to recoup both the initial investment and the cumulative profits earned along the way.

The government's maximization problem yields the following two firstorder conditions:

$$
U^{\prime}[G(k, 1)]-\delta U^{\prime}[G(k, 2)]\left[R^{*}+2 \theta B(k)\right]=0
$$

and

$$
U^{\prime}[G(k, 1)]-\delta U^{\prime}[G(k, 2)]\left[R^{*}+2 \theta B(k)+2 \rho(k) D(k)\right]=0 .
$$

This implies a particular relationship between the composition of capital inflow for country $k$ and its corruption level: 


$$
B(k) / D(k)=[\theta+\rho(k)] / \theta .
$$

Hence, the higher the level of corruption in country $k$, the less FDI it will receive relative to its bank borrowing. This will be the basis of the subsequent empirical examination.

\section{Ratio of Bank Loans to FDI}

Asking whether corruption affects the composition of capital inflows is equivalent to asking whether corruption affects FDI and international bank loans differently. I start by examining the relationship between corruption and bilateral bank lending, in a manner analogous to the earlier section on bilateral FDI (except that government policies toward FDI and the tax rate on firms with foreign participation are omitted). ${ }^{35}$

Table 9 reports four regressions with different specifications (sourcecountry fixed effects with or without host-country random effects). The results are basically consistent across specifications and data sources-and somewhat surprising. When corruption is measured by the GCR/WDR index, it has a positive and statistically significant coefficient. In other words, in contrast with the previous results on FDI, corruption in borrowing countries seems to be associated with a higher level of borrowing from international banks. When corruption is measured by the Transparency International index (results not shown), it still has a positive coefficient, but the estimate is not statistically different from zero at the 10 percent level.

Putting the results on FDI and bank loans together, it would seem natural to expect that corruption would raise the ratio of bank loans to FDI. To verify that this is the case, one can also check directly the connection between the ratio of bank loans to FDI and host-country corruption. We perform a fixed-effects regression of the following sort:

$$
\begin{aligned}
\ln \left(\operatorname{loan}_{j, k} / F D I_{j, k}\right)= & \text { source-country fixed effects } \\
& +\beta(\text { corruption })_{k}+X_{j, k} \Gamma+e_{j, k} .
\end{aligned}
$$

35. I have not found a consistent data source on government policies toward international bank borrowing across countries, nor have I been able to construct such a series from the PwC country reports. 
Table 9. Explaining Investment Lending with Corruption and Other Factors ${ }^{\mathrm{a}}$

\begin{tabular}{|c|c|c|c|c|}
\hline \multirow[b]{2}{*}{ Independent variable } & \multicolumn{2}{|c|}{ Fixed-effects model } & \multicolumn{2}{|c|}{ Random-effects model ${ }^{\mathrm{b}}$} \\
\hline & $9-1$ & $9-2$ & $9-3$ & $9-4$ \\
\hline Corruption & $\begin{array}{l}0.263 * * \\
(0.064)\end{array}$ & $\begin{array}{l}0.215^{* *} \\
(0.062)\end{array}$ & $\begin{array}{l}0.272 * * \\
(0.084)\end{array}$ & $\begin{array}{l}0.213^{* *} \\
(0.084)\end{array}$ \\
\hline Log GDP & $\begin{array}{l}1.004 * * \\
(0.054)\end{array}$ & $\begin{array}{l}0.971 * * \\
(0.052)\end{array}$ & $\begin{array}{l}1.054 * * \\
(0.068)\end{array}$ & $\begin{array}{l}1.003 * * \\
(0.068)\end{array}$ \\
\hline Log GDP per capita & $\begin{array}{l}0.366 * * \\
(0.063)\end{array}$ & $\begin{array}{l}0.341 * * \\
(0.059)\end{array}$ & $\begin{array}{l}0.356 * * \\
(0.081)\end{array}$ & $\begin{array}{l}0.328 * * \\
(0.079)\end{array}$ \\
\hline Log distance & $\begin{array}{l}-0.244 * * \\
(0.072)\end{array}$ & $\begin{array}{l}-0.385^{* *} \\
(0.075)\end{array}$ & $\begin{array}{l}-0.428 * * \\
(0.082)\end{array}$ & $\begin{array}{l}-0.554 * * \\
(0.085)\end{array}$ \\
\hline Presence of linguistic tie & $\begin{array}{l}0.633 * * \\
(0.207)\end{array}$ & $\begin{array}{l}0.650 * * \\
(0.195)\end{array}$ & $\begin{array}{l}0.818 * * \\
(0.198)\end{array}$ & $\begin{array}{l}0.817 * * \\
(0.188)\end{array}$ \\
\hline Exchange rate volatility & $\begin{array}{l}-5.917 * * \\
(1.564)\end{array}$ & $\begin{array}{c}2.420 \\
(1.885)\end{array}$ & $\begin{array}{l}-7.253^{* *} \\
(1.966)\end{array}$ & $\begin{array}{l}2.850 \\
(2.551)\end{array}$ \\
\hline Government deficit & & $\begin{array}{l}-0.075 * * \\
(0.020)\end{array}$ & & $\begin{array}{l}-0.088 * * \\
(0.027)\end{array}$ \\
\hline $\begin{array}{l}\text { Ease of investing in equity } \\
\text { and bond markets }\end{array}$ & $\begin{array}{l}0.219^{* *} \\
(0.088)\end{array}$ & $\begin{array}{c}0.095 \\
(0.088)\end{array}$ & $\begin{array}{l}0.262 * * \\
(0.115)\end{array}$ & $\begin{array}{c}0.103 \\
(0.119)\end{array}$ \\
\hline \multicolumn{5}{|l|}{ Summary statistics } \\
\hline Adjusted $R^{2}$ & 0.72 & 0.75 & $0.73^{\mathrm{c}}$ & $0.76^{\mathrm{c}}$ \\
\hline No. of observations & 396 & 377 & 396 & 377 \\
\hline
\end{tabular}

where $\Gamma$ is a vector of variables other than corruption that may affect either FDI or loans.

The results are reported in table 10, regression equations 10-1 and 10-2. As expected, the coefficient on corruption is positive and statistically significant at the 5 percent level in both regressions. Hence, a corrupt country tends to have a composition of capital inflows that is relatively light in FDI and relatively heavy in bank loans. Also, because FDI is more relationshipintensive (as proxied by physical proximity and linguistic ties) than bank loans, the coefficients on the geographic distance and the linguistic tie variables are positive and negative, respectively, in these regressions.

An array of robustness checks was also performed employing two alternative measures of corruption (the Transparency International index and the German exporters' corruption ratings; results not reported) and an 
Table 10. Explaining the Composition of Capital Inflows

with Corruption and Other Factors ${ }^{\mathrm{a}}$

\begin{tabular}{|c|c|c|c|c|}
\hline \multirow[b]{2}{*}{ Independent variable } & \multicolumn{2}{|c|}{ Fixed-effects model } & \multicolumn{2}{|c|}{ Random-effects model $^{\mathrm{b}}$} \\
\hline & $10-1$ & $10-2$ & $10-3$ & $10-4$ \\
\hline Corruption & $\begin{array}{l}0.410 * * \\
(0.093)\end{array}$ & $\begin{array}{l}0.455^{* *} * \\
(0.093)\end{array}$ & $\begin{array}{l}0.381 * * \\
(0.176)\end{array}$ & $\begin{array}{l}0.475 * * \\
(0.165)\end{array}$ \\
\hline Corporate tax rate & & $\begin{array}{c}0.021 \\
(0.017)\end{array}$ & & $\begin{array}{c}0.022 \\
(0.032)\end{array}$ \\
\hline FDI incentives & & $\begin{array}{c}0.187 \\
(0.153)\end{array}$ & & $\begin{array}{c}0.240 \\
(0.262)\end{array}$ \\
\hline FDI restrictions & & $\begin{array}{l}0.448 * * \\
(0.086)\end{array}$ & & $\begin{array}{l}0.453 * * \\
(0.158)\end{array}$ \\
\hline Log GDP & $\begin{array}{c}-0.342 * * \\
(0.094)\end{array}$ & $\begin{array}{c}-0.606^{* * *} \\
(0.108)\end{array}$ & $\begin{array}{c}-0.392 * * \\
(0.157)\end{array}$ & $\begin{array}{c}-0.695 * * \\
(0.189)\end{array}$ \\
\hline Log GDP per capita & $\begin{array}{c}-0.025 \\
(0.098)\end{array}$ & $\begin{array}{c}0.158 \\
(0.098)\end{array}$ & $\begin{array}{c}-0.019 \\
(0.184)\end{array}$ & $\begin{array}{c}0.193 \\
(0.182)\end{array}$ \\
\hline Log distance & $\begin{array}{l}0.342 * * \\
(0.109)\end{array}$ & $\begin{array}{l}0.350 * * \\
(0.094)\end{array}$ & $\begin{array}{l}0.547 * * \\
(0.123)\end{array}$ & $\begin{array}{l}0.544 * * \\
(0.115)\end{array}$ \\
\hline Presence of linguistic tie & $\begin{array}{c}-0.707 * * \\
(0.328)\end{array}$ & $\begin{array}{c}-0.706^{* * *} \\
(0.307)\end{array}$ & $\begin{array}{c}-0.686^{* * *} \\
(0.294)\end{array}$ & $\begin{array}{c}-0.682 * * \\
(0.288)\end{array}$ \\
\hline Exchange rate volatility & $\begin{array}{c}1.742 \\
(2.245)\end{array}$ & $\begin{array}{c}-0.260 \\
(2.058)\end{array}$ & $\begin{array}{c}2.909 \\
(4.300)\end{array}$ & $\begin{array}{c}0.269 \\
(3.511)\end{array}$ \\
\hline Government deficit & $\begin{array}{c}0.028 \\
(0.030)\end{array}$ & & $\begin{array}{c}0.038 \\
(0.057)\end{array}$ & \\
\hline \multicolumn{5}{|l|}{ Summary statistics } \\
\hline Adjusted $R^{2}$ & 0.41 & 0.48 & $0.43^{\mathrm{c}}$ & $0.51^{\mathrm{c}}$ \\
\hline No. of observations & 238 & 225 & 238 & 225 \\
\hline
\end{tabular}

a. The dependent variable is the log ratio of bank lending to FDI flows, both averaged over 1994-96. See table 4 and appen$\operatorname{dix}$ A for a description of the other variables. Standard errors are in parentheses. $* *$ denotes significance at the 5 percent level.

b. The random effects are discussed in the text.

c. Random-effects regressions report an unadjusted $R^{2}$, as the adjusted measure is not meaningful.

alternative specification (random rather than fixed effects; regression equations 10-3 and 10-4 of table 10). The results are qualitatively similar. In particular, the coefficient estimate on the corruption variable in every regression is positive and statistically significant. Hence, the evidence is overwhelming and robust that corrupt countries tend to have a structure of capital inflows characterized by a relatively small share of FDI.

\section{Instrumental Variables Regressions}

One might be concerned about the possible endogeneity of the corruption measure. For example, survey respondents may perceive a country to 
be corrupt in part because they observe very little FDI going there. In this case the negative association between the loans-to-FDI ratio and corruption could be due to reverse causality. This is of particular concern here, because our reliable measures of corruption were derived in 1996 or later, whereas the most recent FDI and loan data (on a bilateral basis) are from 1996 or earlier.

To address this problem, instrumental variable (IV) regressions were performed on the key specifications. Paolo Mauro has argued that ethnolinguistic fragmentation is a good instrument for corruption. ${ }^{36}$ His ethnolinguistic indicator measures the probability that two persons in a given country are from two distinct ethnic groups. The higher the indicator, the more fragmented the country. In addition, Rafael La Porta and his coauthors have argued that the origin of a country's legal system or its colonial history can have an important impact on the quality of government bureaucracy. ${ }^{37}$ Table 11 reports a regression of the GCR/WDR corruption measure on a constant, a measure of ethnolinguistic fragmentation, and a set of dummies indicating the origin of the country's legal system or colonial history. Ethnically more fragmented countries are found to be more corrupt, and countries with a common-law legal tradition (including former British colonies) are found to be less corrupt than countries with a civil-law tradition (including former French, Spanish, and Portuguese colonies) or countries with German or socialist legal systems.

Table 12 reports the results of the IV regressions using ethnolinguistic fragmentation and legal origins as instruments for corruption. A standard test for overidentified restrictions fails to reject the null hypothesis that the instruments and the error term are not correlated (the $\mathrm{p}$ values of the test for the two regressions are 0.44 and 0.63 , respectively). Thus the chosen variables are valid instruments in a statistical sense, and we see that the results are still consistent with the notion that corruption deters FDI more than bank loans. This indicates that countries that are more corrupt tend to have a capital inflow structure that relies relatively more on bank borrowing and relatively less on FDI.

36. Mauro (1995).

37. La Porta and others (1998). 
Table 11. Corruption Explained by Ethnolinguistic Fragmentation and Type of Legal System ${ }^{\mathrm{a}}$

\begin{tabular}{lc}
\hline Independent variable & Regression coefficient \\
\hline Ethnolinguistic fragmentation $^{\mathrm{b}}$ & $0.029^{* *}$ \\
& $(0.002)$ \\
Legal system of French origin & $1.907^{* *}$ \\
& $(0.157)$ \\
Legal system of German origin & $2.725^{* *}$ \\
& $(0.326)$ \\
Legal system of socialist origin & $2.381^{* *}$ \\
& $(0.320)$ \\
Summary statistics & \\
$R^{2}$ & 0.51 \\
No. of observations & 180 \\
\hline
\end{tabular}

a. The dependent variable is the GCR/WDR corruption index. Countries of British legal origin are the benchmark in the regression. Those of Scandinavian legal origin are omitted because of lack of observations. Standard errors are in parentheses. ** denotes significance at the 5 percent level.

b. The probability that two persons in a given country are from two distinct ethnic groups.

Table 12. Instrumental Variables Regressions Explaining the Composition of Capital Flows ${ }^{\mathrm{a}}$

\begin{tabular}{lcc}
\hline & \multicolumn{2}{c}{ Regression equation } \\
\cline { 2 - 3 } Independent variable & $12-1$ & $12-2$ \\
\hline Corruption $^{\mathrm{b}}$ & $0.214^{*}$ & 0.206 \\
& $(0.129)$ & $(0.130)$ \\
FDI incentives & 0.110 & 0.095 \\
& $(0.156)$ & $(0.157)$ \\
FDI restrictions & $0.336^{* *}$ & $0.333^{* *}$ \\
& $(0.093)$ & $(0.093)$ \\
Log GDP & $-0.274^{* *}$ & $-0.255^{* *}$ \\
& $(0.115)$ & $(0.118)$ \\
Log GDP per capita & 0.035 & 0.033 \\
& $(0.103)$ & $(0.102)$ \\
Log distance & 0.123 & 0.111 \\
& $(0.132)$ & $(0.132)$ \\
Presence of linguistic tie & $-0.752^{* *}$ & $-0.802^{* *}$ \\
& $(0.289)$ & $(0.295)$ \\
Exchange rate volatility & & -1.776 \\
& & $(2.223)$ \\
Summary statistics & & \\
p value for test of overidentified restrictions & & 0.63 \\
$R^{2}$ & 0.44 & 0.46 \\
No. of observations & 0.47 & 180 \\
\hline
\end{tabular}

a. The dependent variable is the log ratio of bank lending to FDI flows, both averaged over 1994-96. See table 4 and appendix A for a description of the other variables. Standard errors are in parentheses. ** denotes significance at the 5 percent level, and $*$ at the 10 percent level.

b. Corruption is instrumented by ethnolinguistic fragmentation and origin of the legal system.

c. The null hypothesis for the test of overidentified restrictions is that $E$ (residual $\times$ instruments $)=0$. 


\section{Portfolio and Direct Investment from the United States}

Although bilateral data on portfolio investment other than bank credit are not available for the whole set of capital-exporting countries examined above, data on portfolio investment from the United States to a set of developing countries are available. These data can be used to examine whether the ratio of portfolio to direct investment in a capital-receiving country is affected by its level of corruption. Note that because the number of observations is small (between thirty-five and thirty-nine, depending on the regression specification), the power of the statistical tests is likely to be low.

Table 13 reports the results of fixed-effects regressions that examine the relationship between the ratio of portfolio investment to FDI and corruption. All three equations use the GCR/WDR indicator of corruption. At least for this subsample of countries, the ratio of portfolio investment to FDI is again positively related to the capital-importing country's level of corruption: the more corrupt a country is, the less FDI it tends to receive relative to portfolio capital. However, in other regressions using the Transparency International corruption index (results not shown), the coefficients on corruption are no longer statistically significant, although they are always positive. Their failure to reach significance is consistent with a genuinely zero coefficient but may also result from the low power of the statistical test due to the small sample size.

\section{Conclusion}

These analyses indicate that corruption in capital-importing countries affects both the volume and the composition of their capital inflows. In particular, corruption reduces inward foreign direct investment substantially. Previous studies of this issue did not take proper account of governments' policies toward FDI. The comprehensive measures reported in this paper of host governments' restrictions on FDI and the incentives they offer to attract FDI are a contribution toward repairing that omission. When these policies are controlled for, corruption in the host country continues to exhibit a negative, statistically significant, and quantitatively large effect on inward FDI.

Although corrupt countries thus receive less FDI than do less corrupt countries, they may not face an equivalent disadvantage in obtaining bank 
Table 13. Explaining the Composition of Capital Flows Using Outward U.S. Portfolio Investment Data ${ }^{a}$

\begin{tabular}{lccc}
\hline & \multicolumn{3}{c}{ Regression equation } \\
\cline { 2 - 4 } Independent variable & $13-1$ & $13-2$ & $13-3$ \\
\hline Corruption & $0.224^{*}$ & $0.223^{*}$ & $0.239 \#$ \\
& $(0.121)$ & $(0.120)$ & $(0.145)$ \\
Corporate tax rate & & -0.023 \\
& & & $(0.036)$ \\
FDI incentives & & -0.218 \\
FDI restrictions & & & $(0.255)$ \\
& & & 0.214 \\
Log GDP & $0.304^{* *}$ & $0.311^{* * *}$ & $(0.156)$ \\
& $(0.138)$ & $(0.152)$ & $0.371^{* *}$ \\
Log GDP per capita & $0.506^{* *}$ & $0.517^{* *}$ & $(0.161)$ \\
& $(0.100)$ & $(0.100)$ & $0.441^{* *}$ \\
Log distance & $-0.200^{*}$ & $-0.187 \#$ & $(0.152)$ \\
Presence of linguistic tie & $(0.101)$ & $(0.113)$ & $-0.194 \#$ \\
& $0.870^{* *}$ & $0.814^{* *}$ & $(0.129)$ \\
Exchange rate volatility & $(0.238)$ & $(0.251)$ & $1.004^{* *}$ \\
Government deficit & & $3.515^{* *}$ & $(0.287)$ \\
& & $(1.649)$ & $3.990 \#$ \\
Ease in investing in equity & & 0.009 & $(2.367)$ \\
and bond markets & & $(0.034)$ & 0.023 \\
Summary statistics & & & $(0.047)$ \\
Adjusted $R^{2}$ & & & $0.364^{*}$ \\
No. of observations & & & $(0.203)$ \\
\hline
\end{tabular}

a. The dependent variable is the log ratio of U.S. portfolio investment to U.S. FDI summed over 1994-96, for a sample of developing countries. See table 4 and appendix A for a description of the other variables. Standard errors are in parentheses. $* *$ denotes significance at the 5 percent level, * at the 10 percent level, and \# at the 15 percent level.

loans. As a result, corruption in a capital-importing country may tend to distort the composition of its capital inflows away from FDI and toward foreign bank loans. The analyses reported in this paper support this hypothesis. Furthermore, the observed effect of corruption on the ratio of borrowing from foreign banks to inward FDI is robust across different measures of corruption and different econometric specifications. There are two possible reasons for this effect. First, FDI is more likely ex post to suffer interference from corrupt local officials than are foreign loans. As a result, less FDI is likely to go to corrupt countries ex ante. Second, the current international financial architecture provides more insurance and other 
protection from the International Monetary Fund and the Group of Seven for bank lenders than for direct investors.

Previous research has shown that a capital inflow structure that is relatively low in FDI is associated with a greater propensity for a future currency crisis. It may be that international bank loans (or other portfolio flows) swing more than direct investment in the event of bad news (whether the "news" is of real events or generated by the investors themselves) about economic or policy fundamentals. If this is the case, this paper has provided evidence for one possible channel through which corruption in a developing country may increase its chances of suffering a crisis.

In the literature on the causes of currency crises, crony capitalism and self-fulfilling expectations on the part of international creditors are often proposed as two rival hypotheses. Indeed, authors who subscribe to one view often reject the other. The evidence in this paper, however, suggests a natural link between the two. Crony capitalism, through its effect on the composition of a country's capital inflows, may make the country more vulnerable to a currency crisis spawned by self-fulfilling expectations.

APPENDIX A

\section{Data Sources and Construction of the Variables}

\begin{tabular}{ll}
\hline Data series & \multicolumn{1}{c}{ Source and description } \\
\hline Bilateral bank lending & $\begin{array}{l}\text { Bank for International Settlements. Data are total loans } \\
\text { outstanding, in millions of dollars, as of the end of December. } \\
\text { Loans to offshore banking centers are omitted. } \\
\text { OECD, International Direct Investment Statistics Yearbook }\end{array}$ \\
Bilateral foreign direct \\
investment flows & $\begin{array}{l}\text { 1998. Data are in millions of dollars, converted using yearly } \\
\text { average exchange rates from annex III of the publication. } \\
\text { Great Circle distance, in kilometers, between the economic } \\
\text { Distance }\end{array}$ \\
$\begin{array}{l}\text { centers (usually the capital cities) of country pairs. Distances } \\
\text { are based on latitude and longitude data from Rudloff (1981), } \\
\text { updated from information in Pearce and Smith (1984). }\end{array}$
\end{tabular}




\begin{tabular}{|c|c|}
\hline Data series & Source and description \\
\hline Linguistic tie & $\begin{array}{l}\text { Major languages for each country are taken from the CIA World } \\
\text { Factbook (www.odci.gov/cia/publications/factbook/). The } \\
\text { variable equals one if the source and the host country share a } \\
\text { common language or one country is a former colony of the } \\
\text { other. Additional languages are assigned for some countries } \\
\text { besides the official languages. }\end{array}$ \\
\hline $\begin{array}{l}\text { GCR corruption } \\
\text { index }\end{array}$ & $\begin{array}{l}\text { Global Competitiveness Report } 1997 \text { (World Econimic Forum } \\
\text { and Harvard Institute for International Development, 1997). } \\
\text { Values of the index used in this paper are calculated as } 8 \\
\text { minus the original value. }\end{array}$ \\
\hline $\begin{array}{l}\text { WDR corruption } \\
\text { index }\end{array}$ & $\begin{array}{l}\text { World Bank, World Development Report } 1997 \text { (World Bank, } \\
\text { 1997). Values of the index used in this paper are calculated as } \\
8 \text { minus the original value. }\end{array}$ \\
\hline $\begin{array}{l}\text { German exporters' } \\
\text { corruption index }\end{array}$ & $\begin{array}{l}\text { Data were "assembled by Peter Neumann (1994) and his } \\
\text { collaborators at Impulse, a German business publication. } \\
\text { Neumann's strategy consisted in interviewing people with } \\
\text { business experience in each of the countries included in the } \\
\text { study, especially concentrating on German exporters who } \\
\text { normally had business in the countries concerned. On average, } \\
10 \text { individuals were interviewed per country (the minimum } \\
\text { number was 3) with a guarantee of confidentiality on their } \\
\text { identities. This index (CORRGEX) indicates the proportion of } \\
\text { the total number of deals that involved corrupt payments." } \\
\text { (p. 1031) The data were first used in Ades and Di Tella (1997), } \\
\text { from which the above description is quoted, and were kindly } \\
\text { made available to the author by Rafael Di Tella. }\end{array}$ \\
\hline Transparency & Transparency International (www.gwdg.de/ uwvw/icr.htm) \\
\hline International index & $\begin{array}{l}1998 \text { index. Values of the index in this paper are calculated as } \\
10 \text { minus the original value. }\end{array}$ \\
\hline GDP & $\begin{array}{l}\text { World Bank SIMA/GDF and WDI central database. GDP data } \\
\text { are at market prices in constant } 1995 \text { dollars. }\end{array}$ \\
\hline GDP per capita & $\begin{array}{l}\text { GDP data from the above source divided by country } \\
\text { population. }\end{array}$ \\
\hline $\begin{array}{l}\text { Exchange rate } \\
\text { volatility }\end{array}$ & $\begin{array}{l}\text { Exchange rate data are from International Monetary Fund, } \\
\text { International Financial Statistics, via the World Bank SIMA } \\
\text { database. }\end{array}$ \\
\hline Government deficit & $\begin{array}{l}\text { World Bank SIMA/GDF and WDI central database. Data are } \\
\text { expressed as a percentage of GDP. }\end{array}$ \\
\hline $\begin{array}{l}\text { U.S. bilateral portfolio } \\
\text { investment flows }\end{array}$ & $\begin{array}{l}\text { U.S. Treasury Department (www.ustreas.gov/tic/ticsec.shtml). } \\
\text { Data for each country are the sum of U.S. portfolio investment } \\
\text { in the country (gross sales by foreigners of foreign bonds and } \\
\text { foreign stocks to U.S. residents) from } 1994 \text { to 1996, in } \\
\text { millions of dollars. }\end{array}$ \\
\hline Legal system origin & La Porta and others (1998). \\
\hline
\end{tabular}




\begin{tabular}{|c|c|}
\hline Data series & Source and description \\
\hline Accounting standards & $\begin{array}{l}\text { La Porta and others (1998). The index was "created by } \\
\text { examining and rating companies' } 1990 \text { annual reports on their } \\
\text { inclusion or omission of } 90 \text { items. These items fall into } \\
\text { seven categories (general information, income statements, } \\
\text { balance sheets, funds flow statement, accounting standards, } \\
\text { stock data and special items). A minimum of three companies } \\
\text { in each country were studied. The companies represent a } \\
\text { cross-section of various industry groups; industrial companies } \\
\text { represent } 70 \text { percent and financial companies represented the } \\
\text { remaining } 30 \text { percent" (p. 1125). }\end{array}$ \\
\hline Corporate tax rate & PricewaterhouseCoopers (2000), updating GCR (1997). \\
\hline
\end{tabular}

APPENDIX B

Corruption Indexes, Corporate Tax Rates, and GDP per Capita by Country

\begin{tabular}{|c|c|c|c|c|c|}
\hline \multirow[b]{2}{*}{ Country } & \multicolumn{3}{|c|}{ Corruption index } & \multirow{2}{*}{$\begin{array}{c}\text { Corporate } \\
\text { tax rate } \\
\text { (percent) }\end{array}$} & \multirow{2}{*}{$\begin{array}{c}\text { GDP } \\
\text { per capita }^{\mathrm{a}} \\
(1995 \text { dollars }\end{array}$} \\
\hline & $G C R / W D R$ & $\begin{array}{l}\text { Transparency } \\
\text { International }\end{array}$ & $\begin{array}{c}\text { German } \\
\text { exporters }\end{array}$ & & \\
\hline Albania & 4.4 & & & & 749 \\
\hline Algeria & & & 4 & & 1,373 \\
\hline Angola & & & 6 & & 462 \\
\hline Argentina & 4.5 & 7.0 & 6 & 30 & 7,767 \\
\hline Armenia & 4.5 & & 6 & & 766 \\
\hline Australia & 2.0 & 1.3 & 0 & 33 & 18,795 \\
\hline Austria & 1.8 & 2.5 & 0 & 34 & 26,838 \\
\hline Azerbaijan & 5.5 & & 6 & & 492 \\
\hline Bangladesh & & & 10 & & 314 \\
\hline Belarus & 5.0 & 6.1 & 4 & & 1,875 \\
\hline $\begin{array}{l}\text { Belgium and } \\
\text { Luxembourg }\end{array}$ & 2.5 & 4.4 & 0 & 40 & 10,365 \\
\hline Benin & 5.0 & & & & 368 \\
\hline Bolivia & 4.2 & 7.2 & 8 & & 905 \\
\hline Botswana & & 3.9 & & & 3,179 \\
\hline Brazil & 4.2 & 6.0 & 8 & 41 & 4,107 \\
\hline Bulgaria & 5.5 & 7.1 & 4 & 36 & 1,394 \\
\hline Cameroon & 5.2 & 8.6 & 6 & & 608 \\
\hline Canada & 1.7 & 0.8 & 0 & 38 & 18,027 \\
\hline Chad & 4.8 & & & & 217 \\
\hline
\end{tabular}




\begin{tabular}{|c|c|c|c|c|c|}
\hline \multirow[b]{2}{*}{ Country } & \multicolumn{3}{|c|}{ Corruption index } & \multirow{2}{*}{$\begin{array}{c}\text { Corporate } \\
\text { tax rate } \\
\text { (percent) }\end{array}$} & \multirow{2}{*}{$\begin{array}{c}\text { GDP } \\
\text { per capita } \\
(1995 \text { dollars }\end{array}$} \\
\hline & $G C R / W D R$ & $\begin{array}{l}\text { Transparency } \\
\text { International }\end{array}$ & $\begin{array}{c}\text { German } \\
\text { exporters }\end{array}$ & & \\
\hline Chile & 2.3 & 3.2 & 2 & 35 & 3,868 \\
\hline China & 4.1 & 6.5 & 8 & 30 & 543 \\
\hline Colombia & 5.1 & 7.8 & 8 & 30 & 1,928 \\
\hline $\begin{array}{l}\text { Congo, } \\
\text { Dem. Rep. of }\end{array}$ & & & 8 & & 144 \\
\hline Congo, Rep. of & 5.2 & & 6 & & 832 \\
\hline Costa Rica & 4.3 & 4.4 & 4 & 30 & 2,479 \\
\hline Côte d'Ivoire & 4.9 & 6.9 & 6 & & 735 \\
\hline Czech Rep. & 3.3 & 5.2 & 4 & 35 & 4,569 \\
\hline Denmark & 1.6 & 0.0 & 0 & 34 & 32,332 \\
\hline Dominican Rep. & & & 4 & & 1,538 \\
\hline Ecuador & 4.6 & 7.7 & 4 & & 1,564 \\
\hline $\begin{array}{l}\text { Egypt, } \\
\text { Arab Rep. of }\end{array}$ & 2.0 & 7.1 & 8 & 42 & 950 \\
\hline El Salvador & 4.5 & 6.4 & & & 1,652 \\
\hline Estonia & 2.6 & 4.3 & 2 & & 3,229 \\
\hline Ethiopia & & & 4 & & 104 \\
\hline Fiji & 2.9 & & & & 2,477 \\
\hline Finland & 1.3 & 0.4 & 0 & 28 & 22,899 \\
\hline France & 2.6 & 3.3 & 0 & 33.3 & 24,602 \\
\hline Gabon & & & 6 & & 4,473 \\
\hline Georgia & 5.0 & & 4 & & 574 \\
\hline Germany & 2.0 & 2.1 & 0 & 42 & 27,549 \\
\hline Ghana & 4.3 & 6.7 & 6 & & 379 \\
\hline Greece & 5.0 & 5.1 & 6 & 40 & 10,272 \\
\hline Guatemala & 5.4 & 6.9 & & & 1,460 \\
\hline Guinea & 5.2 & & & & 558 \\
\hline Guinea-Bissau & 3.7 & & & & 234 \\
\hline Honduras & 5.4 & 8.3 & & & 701 \\
\hline Hong Kong & 1.8 & 2.2 & 0 & 16.5 & 21,167 \\
\hline Hungary & 3.9 & 5.0 & 6 & 18 & 4,075 \\
\hline Iceland & 4.3 & 0.7 & & 33 & 24,656 \\
\hline India & 5.1 & 7.1 & 8 & 40 & 365 \\
\hline Indonesia & 5.5 & 8.0 & 10 & 30 & 973 \\
\hline $\begin{array}{l}\text { Iran, Islamic } \\
\text { Rep. of }\end{array}$ & & & 10 & & 1,416 \\
\hline Ireland & 1.9 & 1.8 & 0 & 32 & 16,643 \\
\hline Israel & 2.7 & 2.9 & 2 & 36 & 14,475 \\
\hline Italy & 4.1 & 5.4 & 6 & 37 & 17,617 \\
\hline Jamaica & 3.1 & 6.2 & & & 1,648 \\
\hline Japan & 2.2 & 4.2 & 0 & 37.5 & 38,514 \\
\hline Jordan & 4.5 & 5.3 & 4 & & 1,548 \\
\hline Kazakhstan & 5.1 & & 4 & & 1,277 \\
\hline
\end{tabular}




\begin{tabular}{|c|c|c|c|c|c|}
\hline \multirow[b]{2}{*}{ Country } & \multicolumn{3}{|c|}{ Corruption index } & \multirow{2}{*}{$\begin{array}{c}\text { Corporate } \\
\text { tax rate } \\
\text { (percent) }\end{array}$} & \multirow{2}{*}{$\begin{array}{c}G D P \\
\text { per capita }^{\mathrm{a}} \\
\left(1995 \text { dollars }^{2}\right)\end{array}$} \\
\hline & $G C R / W D R$ & $\begin{array}{l}\text { Transparency } \\
\text { International }\end{array}$ & $\begin{array}{c}\text { German } \\
\text { exporters }\end{array}$ & & \\
\hline Kenya & 4.3 & 7.5 & 6 & & 333 \\
\hline Korea, Rep. of & 4.3 & 5.8 & 6 & 28 & 9,428 \\
\hline Kuwait & & & 6 & & 15,987 \\
\hline Kyrgyz Rep. & 4.9 & & 4 & & 767 \\
\hline Latvia & 4.6 & 7.3 & 4 & & 2,516 \\
\hline Lithuania & 3.9 & & 0 & & 1,863 \\
\hline Madagascar & 5.0 & & & & 238 \\
\hline Malawi & 3.1 & 5.9 & & & 149 \\
\hline Malaysia & 4.0 & 4.7 & 4 & 28 & 3,951 \\
\hline Mali & 4.4 & & & & 252 \\
\hline Mauritius & 3.5 & 5.0 & & & 3,543 \\
\hline Mexico & 4.4 & 6.7 & 6 & 34 & 3,047 \\
\hline Moldova & 5.0 & & & & 698 \\
\hline Morocco & 4.6 & 6.3 & 4 & 36 & 1,242 \\
\hline Mozambique & 4.4 & & & & 124 \\
\hline Namibia & & 4.7 & 2 & & 2,159 \\
\hline Netherlands & 1.8 & 1.0 & 0 & 35 & 24,104 \\
\hline New Zealand & 1.8 & 0.6 & 0 & 38 & 15,488 \\
\hline Nicaragua & 5.5 & 7.0 & & & 454 \\
\hline Nigeria & 3.8 & 8.1 & 10 & & 256 \\
\hline Norway & 1.4 & 1.0 & 0 & 28 & 31,579 \\
\hline Pakistan & & 7.3 & 10 & & 500 \\
\hline Paraguay & 4.5 & 8.5 & 8 & & 1,839 \\
\hline Peru & 3.4 & 5.5 & 6 & 30 & 2,471 \\
\hline Philippines & 5.5 & 6.7 & 10 & 35 & 989 \\
\hline Poland & 4.6 & 5.4 & 4 & 32 & 2,870 \\
\hline Portugal & 2.7 & 3.5 & 0 & 36 & 9,865 \\
\hline Romania & & 7.0 & 6 & & 1,340 \\
\hline Russia & 5.3 & 7.6 & 8 & 35 & 2,198 \\
\hline Saudi Arabia & & & 8 & & 6,227 \\
\hline Senegal & 4.4 & 6.7 & 8 & & 541 \\
\hline Sierra Leone & & & 6 & & 202 \\
\hline Singapore & 1.6 & 0.9 & 0 & 26 & 26,502 \\
\hline Slovak Rep. & 3.6 & 6.1 & 4 & 40 & 3,043 \\
\hline Slovenia & & & 2 & & 8,770 \\
\hline South Africa & 3.4 & 4.8 & 0 & 35 & 3,189 \\
\hline Spain & 2.8 & 3.9 & 6 & 35 & 13,307 \\
\hline Sweden & 1.4 & 0.5 & 0 & 28 & 24,281 \\
\hline Switzerland & 1.8 & 1.1 & 0 & 23 & 40,708 \\
\hline Syrian Arab Rep. & & & 6 & & 1,156 \\
\hline Taiwan & 3.3 & 5.3 & 6 & 25 & 11,452 \\
\hline Tajikistan & & & 4 & & 297 \\
\hline Tanzania & 5.0 & 8.1 & 6 & & 168 \\
\hline
\end{tabular}




\begin{tabular}{|c|c|c|c|c|c|}
\hline \multirow[b]{2}{*}{ Country } & \multicolumn{3}{|c|}{ Corruption index } & \multirow{2}{*}{$\begin{array}{c}\text { Corporate } \\
\text { tax rate } \\
\text { (percent) }\end{array}$} & \multirow{2}{*}{$\begin{array}{c}\text { GDP } \\
\text { per capita }^{\mathrm{a}} \\
\text { (1995 dollars) }^{\text {(19) }}\end{array}$} \\
\hline & $G C R / W D R$ & $\begin{array}{l}\text { Transparency } \\
\text { International }\end{array}$ & $\begin{array}{c}\text { German } \\
\text { exporters }\end{array}$ & & \\
\hline Thailand & 5.5 & 7.0 & 10 & 30 & 2,620 \\
\hline Togo & 4.2 & & & & 321 \\
\hline Tunisia & & 5.0 & 4 & & 2,042 \\
\hline Turkey & 4.2 & 6.6 & 4 & 33 & 2,606 \\
\hline Turkmenistan & & & 4 & & 980 \\
\hline Uganda & 4.4 & 7.4 & 6 & & 299 \\
\hline Ukraine & 4.3 & 7.2 & 4 & 30 & 1,575 \\
\hline $\begin{array}{l}\text { United Arab } \\
\text { Emirates }\end{array}$ & & & 8 & 0 & 17,147 \\
\hline United Kingdom & 1.5 & 1.3 & 0 & 30 & 17,615 \\
\hline United States & 1.9 & 2.5 & 0 & 35 & 25,078 \\
\hline Uruguay & & 5.7 & 4 & & 5,739 \\
\hline Uzbekistan & 5.2 & & 4 & & 990 \\
\hline Venezuela & 5.2 & 7.7 & 8 & 34 & 3,260 \\
\hline Vietnam & 5.3 & 7.5 & & 33 & 274 \\
\hline Zambia & 3.3 & 6.5 & 8 & & 401 \\
\hline Zimbabwe & 3.9 & 5.8 & 6 & 37.5 & 665 \\
\hline
\end{tabular}

Source: See appendix A.

a. Average for 1994-96. 
APPENDIX C

Robustness Checks

Table C1. Explaining Foreign Direct Investment Adding

Host-Country Random Effects ${ }^{\mathrm{a}}$

\begin{tabular}{lcccc}
\hline & \multicolumn{4}{c}{ Regression equation } \\
\cline { 2 - 5 } Independent variable & $C 1-1$ & $C 1-2$ & $C 1-3$ & $C 1-4^{\mathrm{b}}$ \\
\hline Corruption & $-0.338^{* *}$ & $-0.289^{* *}$ & $-0.180^{*}$ & $-0.205^{* *}$ \\
& $(0.109)$ & $(0.113)$ & $(0.104)$ & $(0.073)$ \\
Corporate tax rate & $-0.035^{*}$ & $-0.039^{* *}$ & -0.002 & -0.003 \\
FDI incentives & $(0.019)$ & $(0.019)$ & $(0.019)$ & $(0.013)$ \\
& & $0.371^{* *}$ & 0.259 & $0.275^{* *}$ \\
FDI restrictions & & $(0.154)$ & $(0.158)$ & $(0.111)$ \\
& & $-0.340^{* *}$ & $-0.278^{* *}$ & $-0.294^{* *}$ \\
Log GDP & $0.977^{* *}$ & $(0.095)$ & $(0.088)$ & $(0.060)$ \\
& $(0.079)$ & $\left(0.960^{* *}\right.$ & $1.114^{* *}$ & $1.040^{* *}$ \\
Log GDP per capita & -0.113 & -0.106 & $(0.083)$ & $(0.057)$ \\
& $(0.126)$ & $(0.141)$ & -0.009 & 0.026 \\
Log distance & $-0.873^{* *}$ & $-0.844^{* *}$ & $-0.865^{* *}$ & $(0.085)$ \\
Presence of linguistic tie & $(0.067)$ & $(0.067)$ & $(0.071)$ & $\left(0.056^{* *}\right.$ \\
& $1.098^{* *}$ & $1.064^{* *}$ & $1.028^{* *}$ & $1.232^{* *}$ \\
Exchange rate volatility & $(0.195)$ & $(0.195)$ & $(0.204)$ & $(0.214)$ \\
& & & 0.928 & 2.388 \\
Government deficit & & & $(2.971)$ & $(2.110)$ \\
& & & $-0.116^{* *}$ & $-0.096^{* *}$ \\
Summary statistics & & & $(0.024)$ & $(0.016)$ \\
$R^{2}$ & 0.73 & 0.73 & 0.76 & 0.76 \\
No. of observations & 658 & 628 & 580 & 580 \\
\hline
\end{tabular}

a. The dependant variable is the logarithm of annual bilateral flows of FDI between source and host countries (averaged over 1994-96). The random effects are discussed in the text. Other independent variables are defined as in table 4 and appendix A. Standard errors are in parentheses. ** denotes significance at the 5 percent level, and $*$ at the 10 percent level.

b. Reprints regression equation 4-3 in table 4 . 


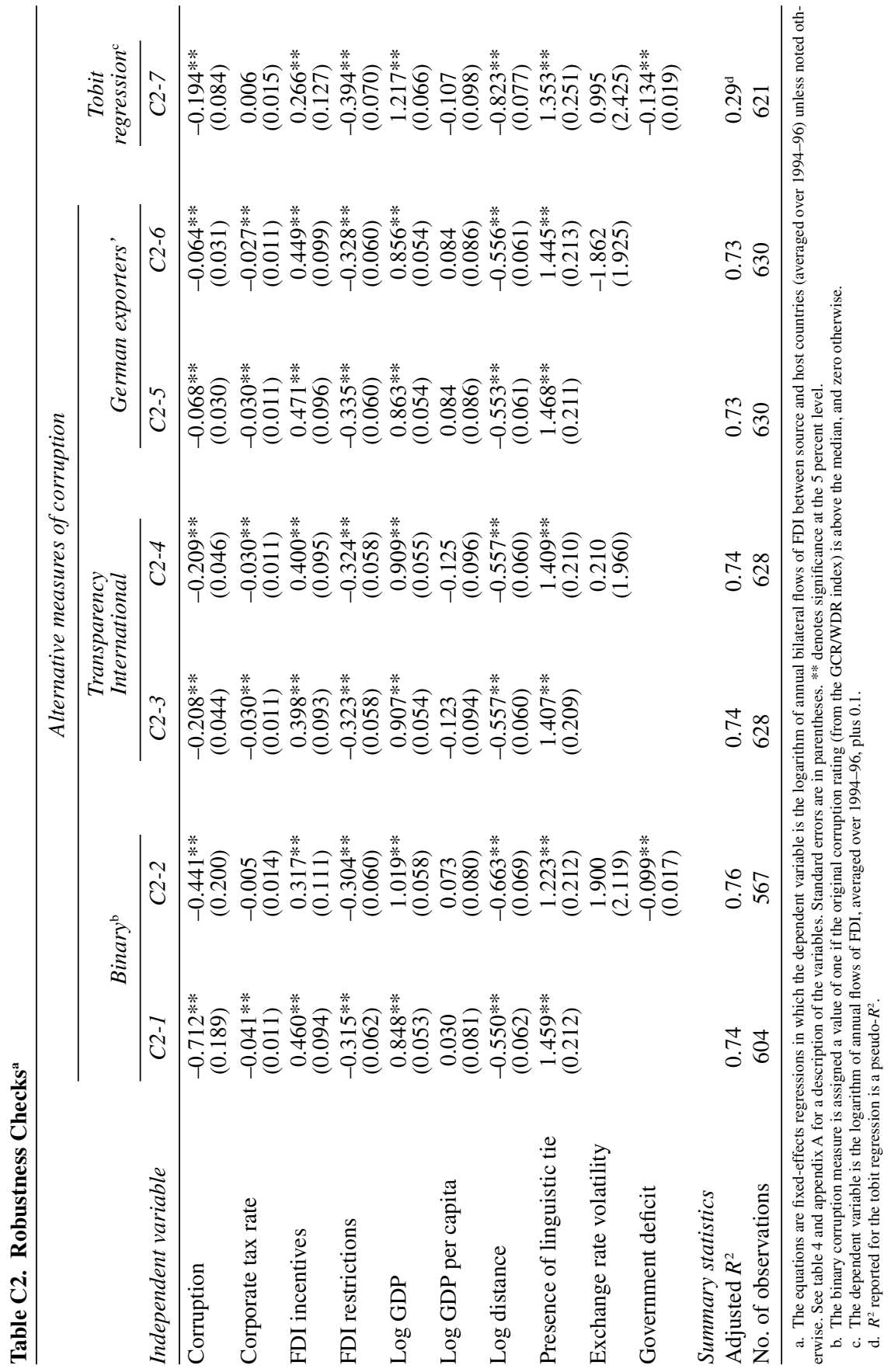




\section{Comment and Discussion}

Andrei Shleifer: Shang-Jin Wei's paper is an important addition to the growing literature on the relationship between institutions and economic outcomes. By and large, this literature shows that poor public sector institutions have great power in explaining poor economic outcomes from slow growth, to low investment (both domestic and foreign), to low educational attainment, to high infant mortality. As Wei also points out, poor institutions of law and corporate governance are increasingly seen as responsible-perhaps far more responsible than poor macroeconomic conditions or even macroeconomic policies-for the depth of the recent Asian financial crisis. The crucial paper in this area is that by Simon Johnson and his coauthors. ${ }^{1}$ These authors examine the depth of the crisis as measured by currency depreciations and stock market declines across emerging market economies. Like others, they find that macroeconomic variables, whether measures of precrisis conditions or of crisis policies, have only limited power in explaining the variation in the depth of the crisis across countries. In contrast, simple measures of law and order and the extent of protection of shareholders have a great deal of explanatory power. Thus economies with the best institutions, such as Singapore and Hong Kong, experienced the mildest crises, whereas those with the weakest institutions, such as the Philippines and Russia, suffered the deepest.

The paper by Johnson and his colleagues has another message relevant to understanding Wei's results, namely, that it is difficult to say precisely which of a number of poor institutions are responsible for the depth of the crisis. The point can be made more generally. Various measures of

1. Johnson and others (2000). 
institutional quality, even when they come from different sources, and even when they address conceptually distinct aspects of the quality of government, are strongly positively correlated with each other. One paper in which this point comes out clearly is that by Rafael La Porta and others. ${ }^{2}$ These authors show strong positive correlations among such indexes of the quality of government as those measuring property rights protection, the quality of regulation, corruption, bureaucratic delay, and tax compliance. Moreover, when predicting various social outcomes, such as school attainment or infant mortality, nearly all of these variables have some predictive power, and it is impossible to tell which one makes the crucial difference. Nor does an instrumental variables procedure solve this problem, since the same potential instruments, such as ethnolinguistic heterogeneity, geography, and origin of the legal system, have the power to forecast nearly all aspects of institutional quality.

This problem is very important in interpreting Wei's results. His is a paper about corruption and its adverse effects, although he recognizes that corruption may reflect low institutional quality more broadly. I would indeed conjecture that other measures of institutional quality would also have significant predictive power in his regressions. One can thus interpret his evidence as suggesting that poor institutional quality is associated with low levels of foreign capital flows, including foreign direct investment, but not necessarily that corruption is the key feature of this poor institutional quality.

The fact that, empirically, it is difficult to tell which aspect of the quality of government is "causing" poor outcomes is important for a number of reasons. Start with corruption. If we think that corruption itself is responsible for poor outcomes, then strategies to reduce corruption, such as the introduction of checks and balances in the government, better selection procedures for bureaucrats, and so on, become very attractive policies.

But, of course, corruption is endogenous. Countries that have high levels of corruption generally have interventionist and abusively regulating governments. As Samuel Huntington pointed out long ago, corruption might actually be a Pareto-improving response to abusive government policies. ${ }^{3}$ In fact, there is some empirical support for the view that corruption is strongly associated with bad regulation. Simeon Djankov and

2. La Porta and others (1999).

3. Huntington (1968). 
others examined, in a sample of seventy-five countries, policies governing the regulation of entry by new firms. ${ }^{4}$ They found that countries with more regulation of entry, in terms of the number of required permits and licenses, also have more corruption, even when the level of economic development is controlled for. If one takes the view that corruption is just a way around abusive regulation, the policy prescriptions become very different. Rather than aim at corruption, policy reform should focus on reducing regulation, and more generally on reducing government intervention in the economy.

Of course, as I have already indicated, Wei's results may have absolutely nothing to do with corruption, but rather have to do with some other aspect of low institutional quality, such as poor security of property rights or poor quality of the judiciary. Because of the high correlation among these variables, the coefficients on corruption in his regressions might be proxying for these influences as well. The trouble is that, if this is the case, the policy prescriptions again change dramatically, depending on which aspect of institutional quality is doing the damage. If the quality of the judiciary is to blame, then good policies might include selecting and training better judges, simplifying and speeding up judicial procedures, and creating specialized courts, including courts for foreign investors. If poor security of property rights is at issue, the focus should be on the institutions protecting these rights, including courts but also including various regulatory agencies. None of this means that Wei's findings are invalid, but rather that it is necessary to take the next step in understanding the relationship between poor institutions and outcomes in order to decide what to do.

Unfortunately, in this area research is only beginning, and no straightforward conclusion has emerged. In some areas, such as the development of securities markets, it is becoming increasingly clear that some form of public regulation-particularly in the areas of disclosure and protection against expropriation-is needed for markets to develop. ${ }^{5}$ Market mechanisms in this area do not appear to be powerful enough to sustain market development without some institutional protection. In other areas, such as the regulation of entry by new entrepreneurs, wise institutional reform

4. Djankov and others (2000).

5. Glaeser, Johnson, and Shleifer (2000). 
probably includes significant reductions in the role of government regulation, particularly in developing countries. ${ }^{6}$ Perhaps the clearest lesson that emerges from the data is that, as countries develop and become more democratic, many - in fact, nearly all—institutions improve, and this of course has further salutary effects on development. We are learning more and more about these issues, and Wei's paper is another very useful step in our expanding knowledge in this area.

General discussion: Edward Glaeser observed that examining the extent to which foreign direct investment is affected differently from domestic investment could help identify whether Wei's results truly reflected corruption or were picking up effects, such as excessive regulation, that correlated with corruption, as Andrei Shleifer had suggested. Clear regulations on business might be expected to affect both foreign and domestic investment the same, whereas corruption could affect them differently, since getting things done then requires local knowledge of whom to bribe and so forth. If corruption, rather than other characteristics that correlate with it, is driving the results, linguistic similarities and physical proximity might be expected to reduce its effects, although perhaps not in the case of large projects, where it would be worth finding a way to acquire those advantages.

Hélène Rey suggested looking at the motivation of FDI, recognizing that some such investment is undertaken to take advantage of low labor costs and some to access a large domestic market. Variables such as GDP and the square of population address these motivations indirectly, but adding a labor cost variable could sharpen the results. If some elements of the corruption measure were associated with trade barriers, their impact might differ according to the motivation. Thus, differentiating FDI by the motive for it might help identify which features of the corruption variable are most important.

Several participants discussed the problem of identifying the impact of Wei's corruption variable and the problem of choosing instrumental variables. William Dickens noted that the instrumental variables Wei used are not adequate, because even if they are exogenous, they are as likely to be correlated with institutions other than corruption, leaving the problem

6. Djankov and others (2000). 
that Shleifer had identified. Dickens suggested examining episodes in which regimes have changed, presumably leaving institutions in place but creating new corruption, for evidence on the effects of corruption on FDI. However, Glaeser questioned whether one could rely on such a pattern of stable institutions and rising corruption following regime changes. Robert Hall reported that, out of the extensive work that has been done on choosing instruments, the best choice for this type of analysis seemed to be latitude, or mortality in early settlements, which correlates closely with latitude.

Matthew Shapiro observed that the paper took a supply-side approach to corruption by focusing on the pattern of corruption presented by host countries. He suggested also looking at the demand side, that is, how source-country FDI varies according to corruption in the hosts. Source countries have different customs and laws concerning the accommodation of corruption abroad. Differences in source-country laws-both across countries and across time-might provide instrumental variables that can address the endogeneity problem.

In this connection, Shleifer cited work by James Hines showing that after the mid-1970s, when the law was passed that penalizes U.S. firms for bribing foreign governments, U.S. firms suffered problems in markets where they compete with other foreign investors. Wei noted that his results included a variable to account for this U.S. inhibition, but he added that, over his data period, no other country applied such sanctions. 


\section{References}

Ades, Alberto, and Rafael di Tella. 1997. "National Champions and Corruption: Some Unpleasant Interventionist Arithmetic.” Economic Journal 107(443): 1023-42.

Bai, Chong-En, and Shang-Jin Wei. 2000. "Quality of Bureaucracy and OpenEconomy Macro Policies.” Working Paper 7766. Cambridge, Mass.: National Bureau of Economic Research (June).

Bardhan, Pranab. 1997. "Corruption and Development: A Review of Issues.” Journal of Economic Literature 35(3): 1320-46.

Borensztein, Eduardo, Jose De Gregorio, and Jong-Wha Lee. 1995. "How Does Foreign Direct Investment Affect Economic Growth?” Working Paper 5057. Cambridge, Mass.: National Bureau of Economic Research (March).

Djankov, Simeon, and others. 2000. "The Regulation of Entry.” Working Paper 7892. Cambridge, Mass.: National Bureau of Economic Research (September).

Eaton, Jonathan, and Akiko Tamura. 1996. "Japanese and U.S. Exports and Investment as Conduits of Growth." Working Paper 5457. Cambridge, Mass.: National Bureau of Economic Research (February).

Frankel, Jeffrey A., and Andrew K. Rose. 1996. "Currency Crashes in Emerging Markets: An Empirical Treatment." Journal of International Economics 41(3-4): 351-66.

Glaeser, Edward, Simon Johnson, and Andrei Shleifer. 2000. "Coase versus the Coasians." Quarterly Journal of Economics (forthcoming).

Hines, James R., Jr. 1995. "Forbidden Payment: Foreign Bribery and American Business after 1977." Working Paper 5266. Cambridge, Mass.: National Bureau of Economic Research (September).

Huang, Yasheng. 1998. FDI in China: An Asian Perspective. Singapore and Hong Kong: Institute of Southeast Asian Studies and Chinese University Press.

Huntington, Samuel P. 1968. Political Order in Changing Societies. Yale University Press.

Johnson, Simon, and others. 2000. "Corporate Governance in the Asian Financial Crisis.” Journal of Financial Economics 58(1-2): 141-86.

Kaufmann, Daniel. 1997. "Corruption: The Facts.” Foreign Policy 107: 114-31.

Kaufmann, Daniel, and Shang-Jin Wei. 1999. "Does 'Grease Money' Speed up the Wheels of Commerce?" Working Paper 7093. Cambridge, Mass.: National Bureau of Economic Research (April).

La Porta, Rafael, and others. 1998. "Law and Finance." Journal of Political Economy 106(6): 1113-55.

-_-_-_ 1999. "The Quality of Government." Journal of Law, Economics and Organization 15(1): 222-79.

Mauro, Paolo. 1995. "Corruption and Growth.” Quarterly Journal of Economics 110(3): 681-712. 
McKinnon, Ronald I., and Huw Pill. 1996. "Credible Liberalization and International Capital Flows: The 'Overborrowing Syndrome'.” In Financial Deregulation and Integration in East Asia, edited by Takatoshi Ito and Anne O. Krueger. University of Chicago Press.

1999. "Exchange Rate Regimes for Emerging Markets: Moral Hazard and International Overborrowing." Oxford Review of Economic Policy 15(3): 19-38.

Mody, Ashoka, and David Wheeler. 1992. "International Investment Location Decisions: The Case of U.S. Firms." Journal of International Economics 33(1-2): 55-76.

Neumann, Peter. 1994. "Bose: Fast Alle Bestechen.” Impulse, no. 4. Hamburg: Gruner + Jahr AG \& Co., p. 12-6.

Organization for Economic Cooperation and Development. 2000. International Direct Investment Statistics Yearbook 1999. Paris.

Pearce, E. A., and C. G. Smith. 1984. The World Weather Guide. London: Hutchinson.

PricewaterhouseCoopers. 2000. Doing Business and Investing Worldwide (CDROM). New York.

Radelet, Steven, and Jeffrey D. Sachs. 1998. "The East Asian Financial Crisis: Diagnosis, Remedies, Prospects.” BPEA, 1:1998, 1-74.

Razin, Assaf, Efraim Sadka, and Chi-Wa Yuen. 1998. "A Pecking Order of Capital Inflows and International Tax Principles." Journal of International Economics 44(1): 171-81.

Reisen, Helmut. 1999. "After the Great Asian Slump: Towards a Coherent Approach to Global Capital Flows.” Policy Brief 16. Paris: OECD Development Centre.

Rodrik, Dani, and Andres Velasco. 1999. "Short-Term Capital Flows.” In Annual World Bank Conference on Development Economics 1999, edited by Joseph E. Stiglitz and Alan Muet. Washington: World Bank.

Rudloff, Willy. 1981. World-Climates, with Tables of Climatic Data and Practical Suggestions." Stuttgart: Wissenschaftliche Verlagsgesellschaft.

Shleifer, Andrei, and Robert W. Vishny. 1993. "Corruption.” Quarterly Journal of Economics 108(3): 599-617.

Smarzynska, Beata K., and Shang-Jin Wei. 2000. "Corruption and the Composition of Foreign Direct Investment: Firm-Level Evidence.” Working Paper 7969. Cambridge, Mass.: National Bureau of Economic Research (October).

Tornell, Aaron. 1990. "Real vs. Financial Investment: Can Tobin Taxes Eliminate the Irreversibility Distortion?" Journal of Development Economics 32(2): 419-44.

United Nations Conference on Trade and Development. 1998. World Investment Report. New York: United Nations. 
Wei, Shang-Jin. 1997. "Why is Corruption So Much More Taxing Than Tax? Arbitrariness Kills.” Working Paper 6255. Cambridge, Mass.: National Bureau of Economic Research (November).

1999. "Corruption in Economic Development: Beneficial Grease, Minor Annoyance, or Major Obstacle?” Policy Research Working Paper 2048. Washington: World Bank.

_. 2000a. "How Taxing Is Corruption on International Investors?" Review of Economics and Statistics 82(1): 1-11.

_. 2000b. "Natural Openness and Good Government." Working Paper 7765. Cambridge, Mass.: National Bureau of Economic Research (June).

- 2000c. "Why Does China Attract So Little Foreign Direct Investment?" In The Role of Foreign Direct Investment in East Asian Economic Development, edited by Takatoshi Ito and Anne O. Krueger. University of Chicago Press.

World Bank. 1997. World Development Report 1997: The State in a Changing World. Washington.

World Economic Forum. 1997. The Global Competitiveness Report 1997. Geneva. 